\title{
Bioactive compounds of marine dinoflagellate isolates from western Greenland and their phylogenetic association within the genus Alexandrium
}

\author{
Urban Tillmann $^{\mathrm{a}, *}$, Bernd Krock ${ }^{\mathrm{a}}$, Tilman J. Alpermann ${ }^{\mathrm{b}}$, Allan Cembella ${ }^{\mathrm{a}}$ \\ a Alfred Wegener Institute, Am Handelshafen 12, 27570 Bremerhaven, Germany \\ ${ }^{\mathrm{b}}$ Senckenberg Research Institute and Natural History Museum Frankfurt, Senckenberganlage 25, 60325 Frankfurt a.M., Germany
}

\section{A R T I C L E I N F O}

Article history:

Received 7 July 2015

Received in revised form 10 November 2015

Accepted 10 November 2015

\section{Keywords:}

Alexandrium

Greenland

Paralytic shellfish toxins

Lytic compounds

\begin{abstract}
A B S T R A C T
The diversity and biogeography of populations of the toxigenic marine dinoflagellate genus Alexandrium, a major global cause of paralytic shellfish poisoning (PSP), are represented by only a few studies based upon a low number of cultured isolates and remain poorly described in Arctic and sub-Arctic waters. Multiple clonal isolates $(n=22)$ of the Alexandrium tamarense species complex, and a single isolate of $A$. tamutum, were collected from the water column while on board an oceanographic expedition to the west coast of Greenland. After culturing of these isolates under controlled conditions, their phylogenetic affinities within the genus Alexandrium were characterized by sequence analysis of nuclear large subunit (LSU) rDNA. Based upon morphological and molecular genetic criteria, all isolates of the A. tamarense species complex were consistent with membership in the Group I ribotype (previously known as the North American ribotype). Phenotypic signatures were also analyzed based upon their respective profiles of paralytic shellfish toxins (PST) and allelochemical interactions against a target cryptophyte Rhodomonas, as determined by lytic potency. All isolates conforming to the A. tamarense Group I produced PST, but no toxins were detected in A. tamutum P2E2. Unusually, only carbamoyl toxins were produced among the A. tamarense Group I isolates from Greenland; sulfocarbamoyl derivatives, generally present in $A$. tamarense population from other locations, including the Arctic, North Pacific and North Atlantic, were absent from all isolates. Allelochemical activity, causing cell lysis of Rhodomonas, but generally being unrelated to cellular PST, was expressed by all $A$. tamarense isolates and also by $A$. tamutum, but varied widely in potency. Comparison of the genotypic (rDNA) and phenotypic (PST profile, allelochemical activity) characteristics of Greenland isolates with those of other Arctic populations reveals a complex pattern of intra-specific diversity. Estimation of diversity relationships is problematic because of the distinct patterns of divergence and lack of evidence of linkage among the alternative biomarkers and morphology. Nevertheless, such studies are necessary as the basis for constructing hindcasting scenarios and predicting changes in Alexandrium species distribution in the Arctic from the regional to the global scale.
\end{abstract}

(c) 2015 Elsevier B.V. All rights reserved.

\section{Introduction}

The globally distributed marine dinophycean genus Alexandrium Halim forms harmful algal blooms (HABs) primarily in coastal temperate and sub-tropical waters throughout the world (Anderson et al., 2012). Among more than 30 morphologically defined species in this genus, the majority are known to include toxigenic members, capable of biosynthesizing a wide array of

\footnotetext{
* Corresponding author.

E-mail address: urban.tillmann@awi.de (U. Tillmann).
}

well-defined toxins (saxitoxins, spirolides and/or goniodomins). Furthermore, many Alexandrium strains also produce poorly characterized allelochemicals capable of lytic activity against target plankton cells (Tillmann and John, 2002; Tillmann et al., 2008).

The Arctic Ocean and adjacent coastal and sub-Arctic waters represent a relatively under-exploited frontier for discovery of the interactions and relationships within and among Alexandrium populations. This is inspite of the fact that several members of the genus Alexandrium have long been known from Arctic and subArctic waters, e.g. A. ostenfeldii was first described from Iceland (Paulsen, 1904). Generally, a number of surveys have revealed the 
occurrence of several putatively toxigenic dinoflagellates (e.g., Protoceratium reticulatum, Dinophysis spp., Alexandrium spp.) in Arctic-boreal waters, but none were considered purely endemic to the Arctic (Okolodkov and Dodge, 1996) and this biogeographical association was further supported by distributional data from multiple ship expeditions in the Eurasian Arctic (Okolodkov, 2005). The genus Alexandrium is considered to be native to the Norwegian Sea, where it is occasionally associated with paralytic shellfish poisoning (PSP), along the Norwegian coast as far north as $71^{\circ} \mathrm{N}$ (Tangen and Dahl, 1993). In 2013, blooms of Alexandrium and a first identification of PSP toxins in blue mussels were reported from Icelandic waters (Burrell et al., 2013). Other northern records of Alexandrium are available from almost all arctic and subarctic regions, including the Gulf of Alaska (Taylor, 1984; Horner et al., 1997), the Greenland Sea northwest of Spitzbergen (Heimdal, 1983), the Northwestern Passage at Igloolik (Bursa, 1961), the Barents and White Sea (Ratkova and Wassmann, 2005), the Beaufort Sea (Niemi et al., 2011), the Bering Sea (Konovalova, 1993; Selina et al., 2006; Orlova et al., 2007), and the Chukchi Sea (Gu et al., 2013b; Natsuike et al., 2013). Just a few recent papers, however, have reported in detail about toxigenicity, toxin profile, and/or phylogenetic associations of Alexandrium in the Arctic (Baggesen et al., 2012; Gu et al., 2013b; Natsuike et al., 2013; Tillmann et al., 2014) and an integrated perspective is still lacking.

Since the original description (as Gonyaulax tamarensis Lebour) of a taxon now considered to belong to Alexandrium Halim emend Balech, the taxonomic affiliations at the inter- and intrageneric and intraspecific levels have been in a state of flux, with attendant controversies. Particularly within the Alexandrium tamarense species complex, comprising several morphologically defined species (i.e., A. catenella, A. fundyense, A. tamarense), and several closely related taxa formerly assigned to Protogonyaulax Taylor, this has led to frequent nomenclatural inconsistencies. Attempts to produce a consistent taxonomy involving separation of species within this group, based upon morphological features (width of apical pore plate, cellular dimensions, presence of a ventral pore) and phenotypic characteristics (toxin composition, bioluminescence) have been unsuccessful. Earlier molecular approaches to resolve Alexandrium species via electrophoretic patterns of isozymes (Cembella et al., 1988) have now been supplanted by comparisons of nucleic acid sequences, particularly of the large (LSU) and small (SSU) subunit rDNA (Scholin and Anderson, 1994; Scholin et al., 1994). Based upon rDNA phylogenetic relationships, clades of these cryptic species were originally defined and designated according to biogeographical distribution (e.g., North American, Mediterranean, etc. (Scholin et al., 1994; John et al., 2003)), but because of distributional overlap these were later given numerical clade designations (Groups I, II, III, IV, and V) (Lilly et al., 2007; Anderson et al., 2012). Recently, John et al. (2014) have proposed re-definition of these clades as discrete species on the basis of rDNA sequences and integration of morphological features with toxin production capacity, and including limited information on mating compatibility studies, i.e. the biological (or reproductive) species criterion.

In this context, the main objective of the present study was to thoroughly characterize Greenland isolates of Alexandrium. One aspect is to determine how the phylogenetic affinities determined by rDNA analysis of Arctic populations of Alexandrium fit within the genus. Moreover, phenotypic signatures based upon toxin profiles and allelochemical interactions provide an estimate of populationwide intra-specific diversity that can be compared with those of other geographical locations in order to assess biogeographical affinities or the distinctness of endemic populations. The long term perspective is to begin integrating morphological and molecular criteria with phenotypic expression of Artic populations to better understand the evolution of species, e.g. under scenarios of past climatic change. This in turn will form the basis for constructing hindcasting scenarios and predicting changes in Alexandrium species distribution from the regional to the global scale.

\section{Materials and methods}

\subsection{Plankton sampling and preparation}

A total of 45 clonal isolates of Alexandrium spp. were established from a water sample collected at station 516 (Fig. 1), one of several stations sampled along the west coast of Greenland during the ARCHEMHAB cruise aboard the research vessel Maria S. Merian in August 2012 (MSM21/3). Two vertical net tows with a 20- $\mu \mathrm{m}$ mesh Nitex plankton net were conducted through the upper $30 \mathrm{~m}$ of the water column of each station. Total volume of the net tow concentrate was measured and an $18 \mathrm{~mL}$ subsample was fixed with paraformaldehyde (PFA) ( $1 \%$ final concentration) for qualitative and quantitative plankton identification. The rest of each net haul was sequentially filtered through Nitex meshes of 200, 50 and $20 \mu \mathrm{m}$ by gravity filtration and split into aliquots for extraction of lipophilic and hydrophilic toxins. A defined aliquot of each suspended plankton size fraction was pelleted by centrifugation for subsequent PSP toxin analysis.

Seawater samples were taken at standard depths $(3,8$, and $20 \mathrm{~m}$ ) by means of $5 \mathrm{~L}$ Niskin entrapment bottles mounted on a remotely triggered rosette-sampler equipped with a CTD device

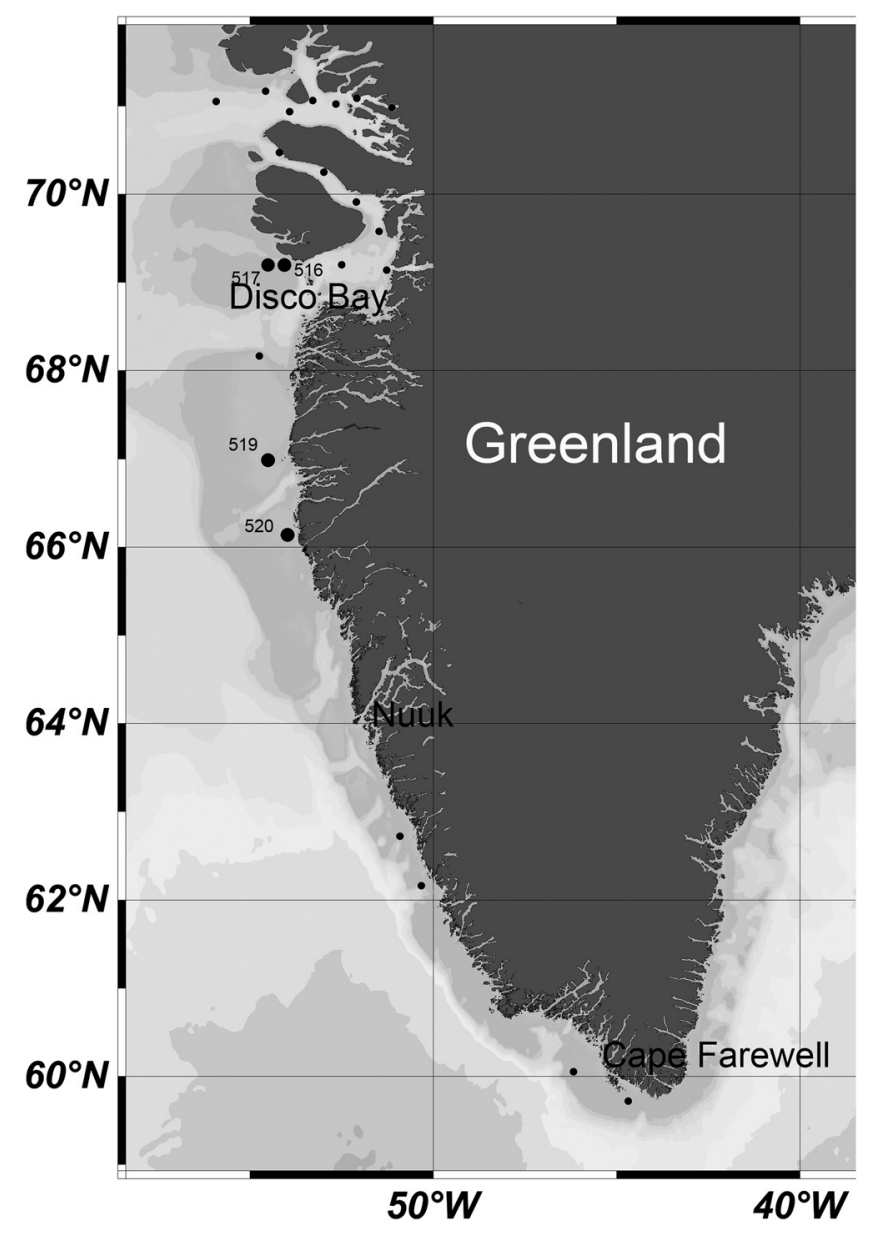

Fig. 1. Map of the sampling locations along the west coast of Greenland during the ARCHEMHAB cruise (Merian MSM21/3). Large dots with numbers indicate stations referred to in the text, small dots indicate additional sampling sites but where no PSP toxins were found in plankton samples. 
and optical sensors. Sub-samples $(50 \mathrm{~mL})$ were preserved with neutral Lugol's iodine solution ( $2 \%$ final concentration) in brown glass bottles and stored under cool and dark conditions for subsequent plankton identification.

\subsection{Analysis of plankton composition}

Qualitative and quantitative characterization of the plankton community at station 516 was conducted by microscopic analysis of both net tow and Niskin bottle samples. For identification and counting of plankton from net tow concentrates, $0.5 \mathrm{~mL}$ of each PFA-fixed sample (corresponding to $0.1 \%$ of the entire net tow) was examined in small sedimentation chambers. From Lugol's iodinefixed Niskin bottle samples, $10 \mathrm{~mL}$ each for all three depths per station were settled in $10 \mathrm{~mL}$ sedimentation chambers. Depending on the cell size and/or abundance of different groups of microalgae, either the plankton content of the whole chamber or in representative sub-areas were counted with an inverted microscope (Axiovert 40C, Zeiss, Göttingen, Germany).

\subsection{Isolation, culturing and harvest of clonal isolates}

Single cells of Alexandrium were isolated onboard by micropipette from live net tow concentrates under a stereomicroscope (M5A, Wild, Heerbrugg, Switzerland). Single cells were transferred into individual wells of 96-well tissue culture plates (TPP, Trasadingen, Switzerland) each containing $250 \mu \mathrm{L}$ of K-medium (Keller et al., 1987), prepared from $0.2 \mu \mathrm{m}$ sterile-filtered natural Antarctic seawater diluted 1:10 with filtered seawater from the sampling location. Plates were incubated on board at $10{ }^{\circ} \mathrm{C}$ under dim light (ca. $30 \mu \mathrm{mol} \mathrm{m} \mathrm{m}^{-2} \mathrm{~s}^{-1}$ ) in a controlled environment growth chamber (Model MIR 252, Sanyo Biomedical, Wood Dale, USA). After 3-4 weeks, clonal isolates were transferred to 24-well tissue culture plates, each well containing $2 \mathrm{~mL}$ of K-medium diluted 1:5 with Antarctic seawater. Exponentially growing isolates were finally used as inoculum for batch cultures in $65 \mathrm{~mL}$ polystyrene cell culture flasks and were maintained thereafter at $10^{\circ} \mathrm{C}$ under a photon flux density of $30-$ $50 \mu \mathrm{mol} \mathrm{m}{ }^{-2} \mathrm{~s}^{-1}$ on a 16:8 h light:dark photocycle in a temperature-controlled growth chamber for subsequent DNA phylogeny, toxin analysis and lytic capacity experiments.

Cell concentrations from exponentially growing cultures were determined by settling Lugol's iodine-fixed samples and counting $>600$ cells under an inverted microscope. Cultures were harvested at cell concentrations ranging from 800 to 9000 cells $\mathrm{mL}^{-1}$ by centrifugation (Eppendorf 5810R, Hamburg, Germany) at $3220 \times g$ for $10 \mathrm{~min}$. Cell pellets were transferred to $1.5 \mathrm{~mL}$ microtubes, then again centrifuged (Eppendorf 5415$)$ at $16,000 \times g(5 \mathrm{~min})$ and stored frozen for subsequent phylogenetic analysis of DNA $\left(-80^{\circ} \mathrm{C}\right)$ and for future analysis of PSP toxin composition $\left(-20^{\circ} \mathrm{C}\right)$.

\subsection{Morphological characterization by microscopy}

Morphological observations and documentation of live and fixed cells was carried out by examination under various microscopy systems (all Zeiss, Göttingen, Germany). Specimens were observed with either an inverted Axiovert $200 \mathrm{M}$ or an Axioskop 2 microscope, both equipped with epifluorescence and differential interference contrast optics. For size measurements and thecal plate pattern analysis, cells were harvested from exponentially growing cultures and preserved with 1\% (final concentration) neutral Lugol's iodine solution. Fixed cells were viewed under the inverted microscope and photographed at $630 \times$ magnification with an Axiocam digital camera. Apical and transapical diameter (length and width) of cells ( $n>50$ from each isolate) were measured with the program Axiovision (v.4.8, Zeiss,
Germany) based upon micrographs taken with an Axiocam MRc digital camera.

For all isolates, species designation was confirmed by fluorescence microscopy of calcofluor-stained samples. Thecal plates were visualized at $1000 \times$ magnification under epifluorescence with an Axioskop 2 microscope, after applying a few drops of a $1 \mathrm{mg} \mathrm{L}^{-1}$ solution of Fluorescent Brightener 28 (Sigma-Aldrich, St. Louis, USA).

\subsection{DNA extraction and phylogenetic analyses}

The LSU rDNA sequences of all Alexandrium tamarense and Alexandrium tamutum isolates and their phylogenetic position were determined after extracting genomic DNA from cell pellets with a DNeasy Plant Mini Kit (Qiagen, Hilden, Germany) according to the manufacturer's instructions and as detailed in Toebe et al. (2013). Genomic DNA was used to amplify the D1/D2 hypervariable region of the LSU of the ribosomal operon by PCR with primers D1R (forward) and D2C (reverse) (Scholin et al., 1994) under PCR chemistry and cycling conditions as in Toebe et al. (2013). Fresh PCR products were cloned into a TOPO ${ }^{\circledR}$ TA sequencing vector (Invitrogen $^{\mathrm{TM}}$, Life Technologies, Darmstadt, Germany) and transformed into One Shot ${ }^{\mathbb{R}}$ TOP10 Electrocomp ${ }^{\mathrm{TM}}$ E. coli (Invitrogen ${ }^{\mathrm{TM}}$ ) according to the manufacturer's protocol. Several positive bacterial colonies of each cloning reaction were transferred into LB medium and grown overnight. Plasmids were purified with a Perfectprep Plasmid 96 Vac Kit (5 Prime, Hilden, Germany) and sequenced by Sanger chain termination methodology with plasmid specific M13 primers and a BigDye ${ }^{\circledR}$ Terminator v3.1 Cycle Sequencing Kit (Applied Biosystems, Darmstadt, Germany). After clean-up with a DyeEx 2.0 Spin Kit (Qiagen), sequence reaction products were read on an ABI 3130XL Genetic Analyzer (Applied Biosystems). Forward and reverse sequences of one PCR clone per Alexandrium isolate were assembled in Geneious Pro 5.4.4 (Biomatters Ltd., Auckland, New Zealand) and then subsequently used in phylogenetic analyses. Unique partial LSU rDNA sequences of the 22 isolates from the A. tamarense species complex (GenBank accessions KP744623-KP744644) were aligned with other sequences representing the five ribotypes of this species complex; sequences of closely related congeners Alexandrium affine, Alexandrium tamiyavanichii and Alexandrium tropicale were used as outgroup (Supplementary Table 1); the partial LSU rDNA sequence of $A$. tamutum isolate P2E2 (GenBank accession KP744645) was included in a separate alignment with all unique sequences of other $A$. tamutum isolates available from GenBank and additionally sequences of closely related congeners and $A$. margalefii as outgroup (Supplementary Table 2). Both alignments were generated in MAFFT v7.017 (Katoh and Kuma, 2002) using a plugin for Geneious Pro. Maximum Likelihood (ML) trees were constructed with the GTR+G model of nucleotide substitution in PAUP* via a plugin in Geneious Pro after determination of the best fitting model of nucleotide substitution by the Akaike Information Criterion in Modeltest (Posada and Crandall, 1998). Reliability of tree topologies was estimated by 200 bootstrap replicates.

\subsection{Analysis of PSP toxin composition}

Cell pellets were suspended with $0.5 \mathrm{~mL} 0.03 \mathrm{M}$ acetic acid and transferred into FastPrep tubes containing $0.9 \mathrm{~g}$ lysing matrix D (Thermo Savant, Illkirch, France). Samples were homogenised by reciprocal shaking at maximum speed $\left(6.5 \mathrm{~m} \mathrm{~s}^{-1}\right)$ in a FastPrep instrument (Thermo Savant, Illkirch, France) and subsequently centrifuged $\left(15 \mathrm{~min}, 4^{\circ} \mathrm{C}, 13,200 \times \mathrm{g}\right.$ ). Supernatants were spun $(60 \mathrm{~s}, 800 \times g)$ through spin filters $(0.45 \mu \mathrm{m}$, Millipore, Eschborn, Germany). The aqueous extracts were analyzed by reverse-phase ion-pair liquid chromatography with fluorescence detection 
(LC-FD) and post-column derivatization following minor modifications of previously published methods (Diener et al., 2006; Krock et al., 2007). The LC-FD analysis was carried out on a LC1100 series liquid chromatography system consisting of a G1379A degasser, a G1311A quaternary pump, a G1229A autosampler, and a G1321A fluorescence detector (Agilent Technologies, Waldbronn, Germany), equipped with a Phenomenex Luna C18 reversed-phase column $(250 \mathrm{~mm} \times 4.6 \mathrm{~mm}$ id, $5 \mu \mathrm{m}$ pore size) (Phenomenex, Aschaffenburg, Germany) with a Phenomenex SecuriGuard precolumn. The column was coupled to a PCX 2500 post-column derivatization system (Pickering Laboratories, Mountain View, CA, USA). Eluent A contained $6 \mathrm{mM}$ octanesulfonic acid, $6 \mathrm{mM}$ heptanesulfonic acid, $40 \mathrm{mM}$ ammonium phosphate, adjusted to pH 6.95 with dilute phosphoric acid, and $0.75 \%$ tetrahydrofuran. Eluent B contained $13 \mathrm{mM}$ octanesulfonic acid, $50 \mathrm{mM}$ phosphoric acid, adjusted to $\mathrm{pH} 6.9$ with ammonium hydroxide, 15\% acetonitrile and $1.5 \%$ tetrahydrofuran. The flow rate was

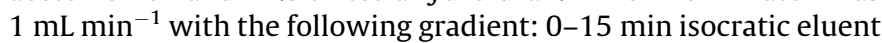
A, 15-16 min switch to eluent $B, 16-35$ min isocratic eluent $B, 35-$ 36 min switch to eluent $A, 36-45$ min isocratic eluent $A$. The injection volume was $20 \mu \mathrm{L}$ and the autosampler was cooled to $4{ }^{\circ} \mathrm{C}$. The eluate from the column was oxidized with $10 \mathrm{mM}$ periodic acid in $555 \mathrm{mM}$ ammonium hydroxide before entering the reaction coil $\left(50{ }^{\circ} \mathrm{C}\right)$, after which it was acidified with $0.75 \mathrm{M}$ nitric acid. Both the oxidizing and acidifying reagents entered the system at a rate of $0.4 \mathrm{~mL} \mathrm{~min}^{-1}$. The toxins were detected by dualmonochromator fluorescence $\left(\lambda_{\text {ex }} 333 \mathrm{~nm} ; \lambda_{\text {em }} 395 \mathrm{~nm}\right)$. The data were processed with Agilent Chemstation software and calibrated against external standards. Standard solutions of PSP toxins were purchased from the Certified Reference Material Programme of the Institute of Marine Biosciences, National Research Council, Halifax, NS, Canada.

\subsection{Estimation of Alexandrium lytic capacity}

Isolates were screened for lytic activity with a cell bioassay based upon exposure to live cells of the cryptophyte Rhodomonas (detailed in Tillmann et al., 2009). Cultures of clonal isolates of Alexandrium tamarense and Alexandrium tamutum were enumerated and subsequently diluted with $\mathrm{K}$-medium to a final cell concentration of approximately $1 \times 10^{3}$ cells $\mathrm{mL}^{-1}$. Then $3.9 \mathrm{~mL}$ of diluted culture was dispensed into triplicate $6 \mathrm{~mL}$ glass vials. Two negative and one positive control (triplicate each) were performed in the same way as the experimental assays. The first negative control contained only K-medium, whereas the second was performed with $A$. tamarense strain Alex5, previously shown to be non-lytic (Tillmann and Hansen, 2009). The positive control was performed by adding culture of the allelochemically active $A$. tamarense strain Alex 2 (Tillmann and Hansen, 2009). Each sample was spiked with $0.1 \mathrm{~mL}$ of a Rhodomonas culture which was adjusted (based on microscope cell counts) to $4 \times 10^{5}$ cells $\mathrm{mL}^{-1}$, thereby yielding an initial start concentration of $1 \times 10^{4}$ cells $\mathrm{mL}^{-1}$ of the target cells in the bioassay. Samples were then incubated for $24 \mathrm{~h}$ in the dark at $10^{\circ} \mathrm{C}$. Subsequently, samples were fixed ( $2 \%$ final concentration) with neutral Lugol's iodine solution and concentration of intact target cells was determined. All counts were performed with an inverted microscope (Zeiss Axiovert 40C, Göttingen, Germany) in small counting chambers with a volume set up for cell counts of $0.5 \mathrm{~mL}$. A sub-area of the chamber corresponding to at least 600 Rhodomonas cells in the control was counted. In order to quantify lytic effects, only intact cells of the target species were scored. Isolates were simultaneously tested in groups of 3-10 isolates in a total of three bioassay runs. All results were expressed as final concentration of Rhodomonas cells expressed as percent of the seawater medium control.

\section{Results}

\subsection{Plankton composition and associated environmental factors}

At station 516 within Disko Bay (Fig. 1), the source of all Alexandrium isolates reported herein, salinity was constantly high (33.2-33.5) in the upper $30 \mathrm{~m}$, with no direct evidence of glacial melting effect on the salinity profile. Surface temperature at this station was $6.8^{\circ} \mathrm{C}$ in the upper $10 \mathrm{~m}$ and decreased steadily to $2.5^{\circ} \mathrm{C}$ at $30 \mathrm{~m}$. In vivo chlorophyll values, as an index of phytoplankton concentration at station 516 , were low to moderate, ranging from 0.23 ( $3 \mathrm{~m}$ depth) to a maximum of $2.04 \mu \mathrm{g} \mathrm{L}^{-1}$ (20 m) (Daniela Voß, unpublished observations).

Based on qualitative inspection of net tow samples ( $>20 \mu \mathrm{m})$, the plankton community could be generally characterized as representing a post spring-bloom, with low abundance of photosynthetic organisms and with a high and diverse proportion of heterotrophs (e.g., tintinnids, aloricate ciliates, rotatoria, heterotrophic dinoflagellates). The sample at station 516 was rather low in biomass and characterized by a variety of dinoflagellate species, with just a few cells of diatoms (e.g., of Cerataulina bergonii, Thalassiosira nordenskiöldii, Leptocylindrus sp.). Highest cellular abundance of microplankton taxa in Niskin bottle samples were of the dinoflagellates Scrippsiella sp. (1.7$3.0 \times 10^{4} \mathrm{~L}^{-1}$, range among samples of three depths) and Protoperidinium spp. $\left(2.5-3.2 \times 10^{4} \mathrm{~L}^{-1}\right)$, unidentified small and medium-sized $(10-30 \mu \mathrm{m})$ dinoflagellates $\left(47-83 \times 10^{4} \mathrm{~L}^{-1}\right)$ and diverse ciliates $\left(1.1-3.0 \times 10^{4} \mathrm{~L}^{-1}\right)$. The highest cell concentrations overall were found for the mixotrophic chrysophyte Dinobryon sp., with up to $1.2 \times 10^{6} \mathrm{~L}^{-1}$ at $15 \mathrm{~m}$ depth.

Species of Alexandrium were found in phytoplankton net-tows from several stations along the west coast of Greenland. The cell concentrations of Alexandrium spp. within Disko Bay were generally low $\left(<1 \times 10^{3} \mathrm{~L}^{-1}\right)$. Based upon samples collected with Niskin bottles at discrete depths, cell concentrations of Alexandrium spp. (not identified to species level) ranged between $100 \mathrm{~L}^{-1}$ at $3 \mathrm{~m}$ to a maximum of $500 \mathrm{~L}^{-1}$ recorded at $15 \mathrm{~m}$. Quantification of Alexandrium spp. in the net tow sample from station 516 indicated an abundance of $1.03 \times 10^{5}$ cells in the whole net tow.

\subsection{Morphological identification and description}

Morphological analysis of Alexandrium spp. by critical microscopy revealed that $A$. tamarense and $A$. tamutum co-occurred with A. ostenfeldii at station 516. Among 45 clonal isolates of Alexandrium obtained from Disko Bight south of Disko Island (Fig. 1), 22 were identified as belonging to A. ostenfeldii. The other isolates were identified to represent two different species, with 22 isolates of $A$. tamarense and one isolate of $A$. tamutum reported herein. The morphology, toxin composition, and phylogenetic associations of the $A$. ostenfeldii isolates from this region have been presented elsewhere (Tillmann et al., 2014)

\subsubsection{Alexandrium tamarense}

Cells of Alexandrium tamarense isolates from western Greenland were almost spherical with a slightly angular outline giving the hyposome a roughly trapezoidal shape (Fig. 2A-E). They contained many dark brown chloroplasts and a horse-shoe shaped nucleus was located in the cingulum plane (Fig. $2 \mathrm{~A}-\mathrm{C}$ ). The cingulum was excavated, left descending, displaced about one cingulum width and with ridges along the sutures with pre- and postcingular plates (Fig. 2B, D).

Cell size was variable and ranged over almost two-fold for all linear dimensions of all isolates ( $n=1205$; cell length: 20.2$40.2 \mu \mathrm{m}$; cell width: $20.9-44.8 \mu \mathrm{m}$ ). Cell size was significantly different among isolates (ANOVA: cell length: $F=65.8, p<0.005$, 


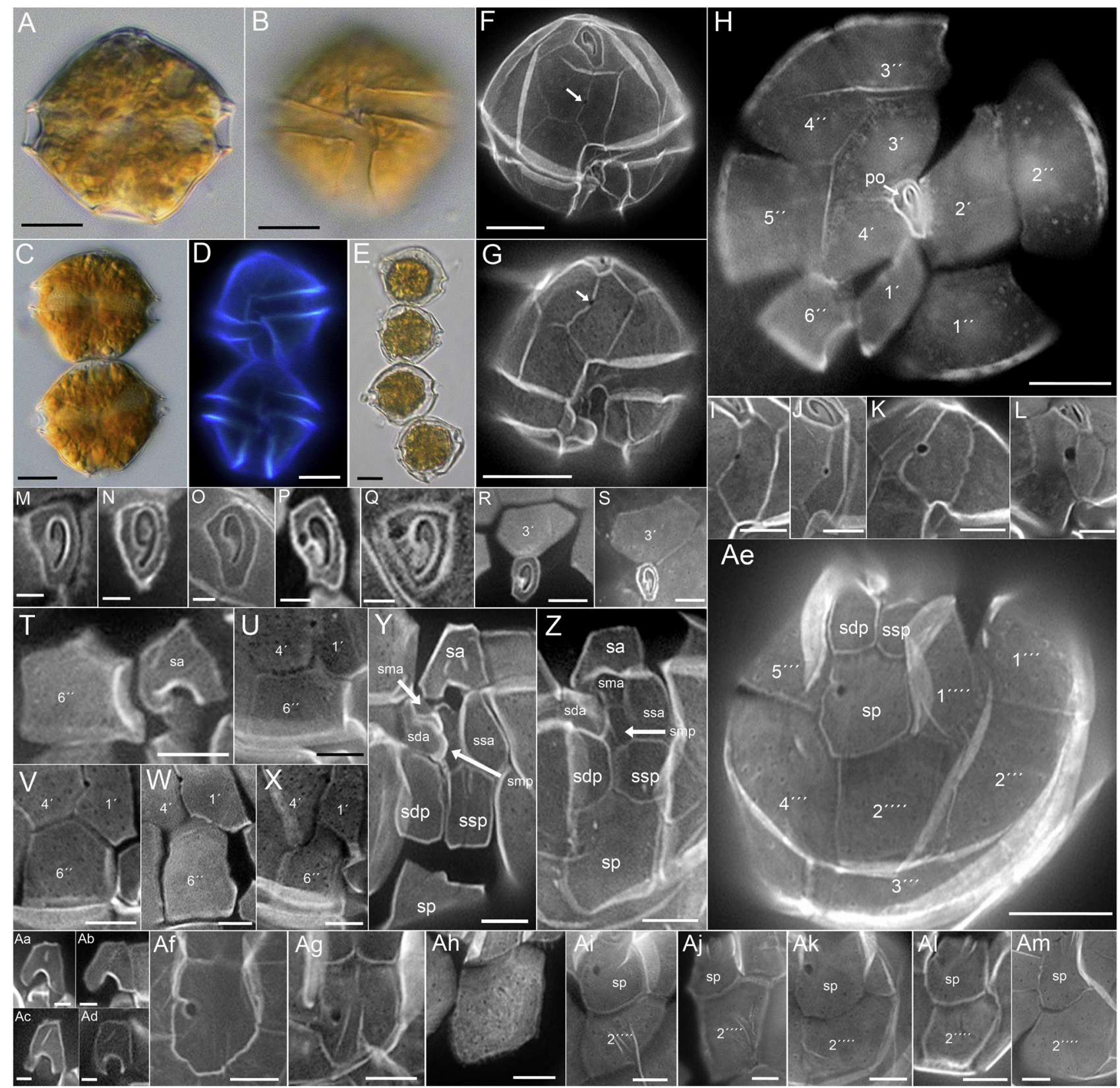

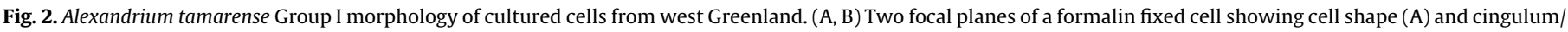

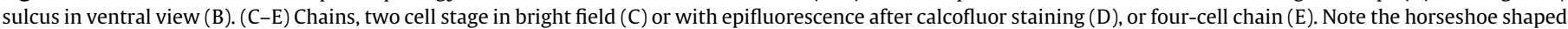

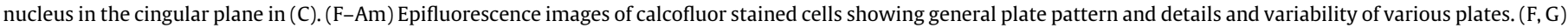

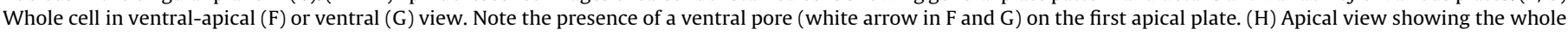

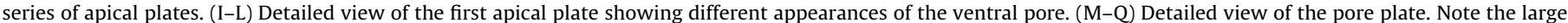

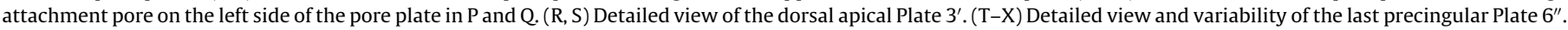

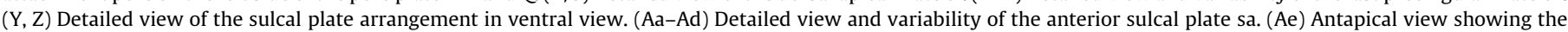

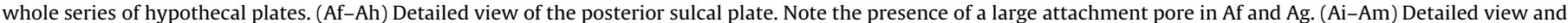

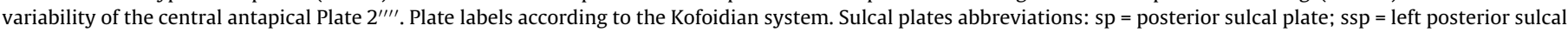

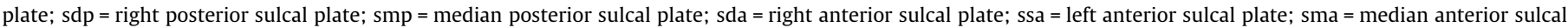
plate; sa = anterior sulcal plate; Scale bar $=10 \mu \mathrm{m}(\mathrm{A}-\mathrm{H}, \mathrm{Ae}), 5 \mu \mathrm{m}(\mathrm{I}-\mathrm{L}, \mathrm{R}-\mathrm{Z}, \mathrm{Af}-\mathrm{Am})$, or $2 \mu \mathrm{m}(\mathrm{M}-\mathrm{Q}, \mathrm{Aa}-\mathrm{Ad})$.

cell width: $F=13.6, p<0.005)$ with median cell length ranging among isolates from 24.6 to $32.1 \mu \mathrm{m}$ (Supplementary Fig. 1A). All isolates exhibited both cells wider than long and longer than wide, but the median length/width ratio (significant difference between strains; ANOVA: $F=34.1, p<0.005$ ) for most isolates was slightly $<1$ (Supplementary Fig. 1B).

For all isolates, pairs of cells (Fig. 2C, D) or chains of four individuals (Fig. 2E) were abundant in exponentially growing cultures.
The Kofoidian plate pattern was invariable for all isolates and was determined as po, 4', 6" $6 \mathrm{C}, 8\left(\right.$ ?)S, 5"', $2^{\prime \prime \prime \prime}$ (Fig. 2H, Y, Ae)

The general shape of the first apical Plate $1^{\prime}$ was asymmetricalrhomboid. All cells ( $n>50$ cells were inspected for every isolate) had a distinct ventral pore located midway or slightly posterior to midway on the right margin of the first apical plate (Fig. 2F, G, I-L). In most cases the pore was rather small (Fig. 2I); however, ventral pores of a distinctly larger size (Fig. 2J-K) were also observed occasionally in a several isolates. Extraordinarily large ventral 
pores (Fig. 2L) were seen in one of the isolates (P3B10) only. When scored for $>100$ cells, $56.5 \%$ of isolate P3B10 cells had a small ventral pore (compare to Fig. $2 \mathrm{I}, \mathrm{J}$ ), whereas $19.8 \%$ had a mediumsized pore (compare to Fig. $2 \mathrm{~K}$ ) and $23.6 \%$ had a large ventral pore (compare to Fig. 2L), respectively.

From the apical plate series, Plate $2^{\prime}$ was large and drawn out dorsally to a truncated tip touching Plate $3^{\prime \prime}$ (Fig. 2H). The dorsal Plate 3' was asymmetric (Fig. 2R, S).

The apical pore plate (po) was irregularly shaped, ranging from oval to tear-drop-shaped, and contained a characteristic commashaped pore (Fig. 2M-Q). Although difficult to clearly see in fluorescence microscopy, the po seemed to have a number of small pores mainly along the left lateral side. Rarely, the anteriorly angled part of the pore extended posteriorly and thus almost perfectly mimicked the number nine (Fig. $2 \mathrm{~N}$ ). A connecting pore was at times present at right of the comma's head (Fig. 2P, Q).

The last precingular Plate $6^{\prime \prime}$ was quite variable in size and shape (Fig. 2T-X). Generally, 6" was as wide as long, although both rather narrow (Fig. 2W) and broader (Fig. 2U) shapes were also observed. The left side was markedly concave and strongly reinforced (Fig. 2T). The anterior margin often had a roof-ridge shape (Fig. 2V). Quite often, however, the anterior suture of $6^{\prime \prime}$ was markedly concave towards the $4^{\prime}$ plate but convex to the $1^{\prime}$ plate, giving the anterior part of $6^{\prime \prime}$ a tooth- or thorn-like appearance (Fig. 2X).

The sulcus was excavated, slightly broadened in its antapical extent and delimited on both sides by sulcal lists on the first antapical plate and the last postcingular plate, respectively (Fig. 2B, D). The sulcal series consisted of at least eight plates (Fig. 2Y, Z). In general, the left and right posterior sulcal plates were longer than wide (Fig. 2Y), but could also be conspicuously broadened (Fig. 2Z). The anterior sulcal plate was slightly variable in shape (Fig. 2AaAd), but mainly A-shaped and longer than wide. Plate sa showed a distinct mark visible as a slanting line in the anterior part (Fig. 2AaAd). The posterior sulcal plate was invariably longer than wide (Fig. 2Z, Ae-Ah). The posterior side was asymmetrically tapered or more rounded, whereas the anterior part was subdivided into two rounded dents representing the borders with the left and right posterior sulcal plates. A large attachment pore on sp was observed for the majority of cells. When present, the attachment pore was prominent, large and almost round, and was connected to the right plate suture with Plate $5^{\prime \prime \prime}$ by a slit (Fig. 2Af).

In the hypotheca, $2^{\prime \prime \prime \prime}$ was pentagonal (Fig. 2Ai-Am) but very variable in shape, alternatively quadratic (Fig. 2Ai), longer than wide (Fig. $2 \mathrm{Aj}$ ) or wider than long (Fig. 2Ak). Generally, Plate $2^{\prime \prime \prime \prime}$ was comparable to or sometimes just slightly larger than the sp plate (Fig. 2Al), although occasionally the $2^{\prime \prime \prime \prime}$ plate was distinctly larger (Fig. 2Am).

\subsubsection{Alexandrium tamutum}

Cells of Alexandrium tamutum strain P2E2 were almost spherical or slightly elliptical in shape with an excavated and left descending cingulum, which was displaced about one cingulum width (Fig. 3A,
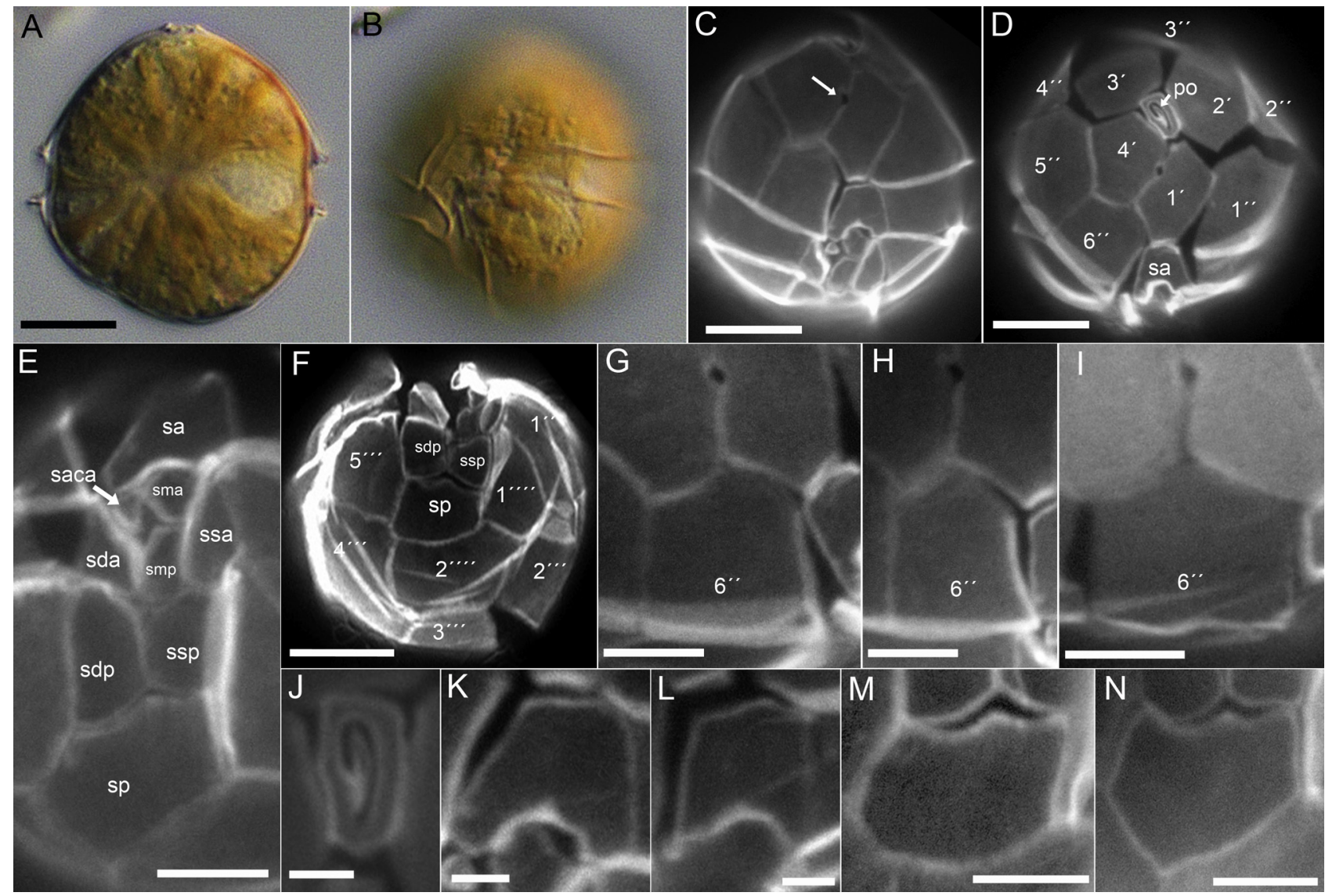

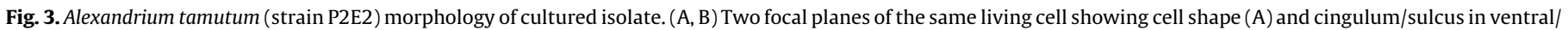

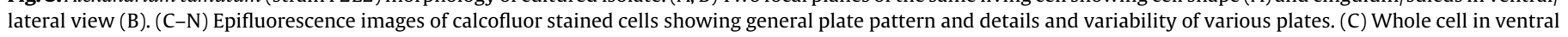

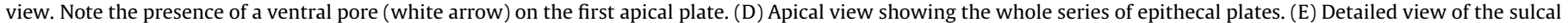

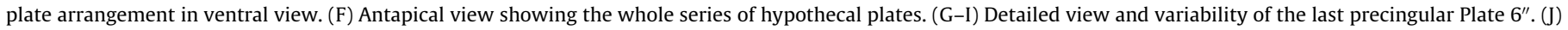

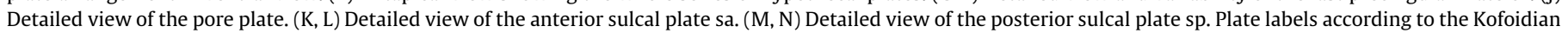

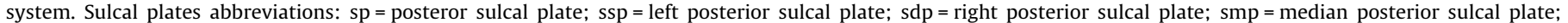

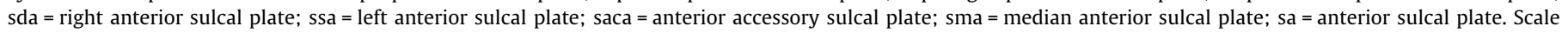
bar $=10 \mu \mathrm{m}(\mathrm{A}-\mathrm{F}), 5 \mu \mathrm{m}(\mathrm{G}-\mathrm{I}, \mathrm{M}, \mathrm{N})$, or $2 \mu \mathrm{m}(\mathrm{J}-\mathrm{L})$. 
B). A typical horseshoe-shaped nucleus was present in the cingulum plane (Fig. 3A). Median cell size was $27.2( \pm 2.1 \mu \mathrm{m}$ SD) in length ( $n=64$; minimum: $23.2 \mu \mathrm{m}$; maximum: $31.7 \mu \mathrm{m})$ and $27.9( \pm 2.0 \mu \mathrm{m} \mathrm{SD})$ in width ( $n=64$; minimum: $22.9 \mu \mathrm{m}$, maximum: $32.5 \mu \mathrm{m}$ ) with a median length/width ratio of 0.99 (see also Supplementary Fig. 1). Cells occurred almost always as singlets; two cell stages, probably close to final cell division, were seen only rarely.

The plate pattern was invariable and determined as po, $4^{\prime}, 6^{\prime \prime}$, 6C, 9(?)S, 5"', $2^{\prime \prime \prime \prime}$ (Fig. 3C-F). The pore plate was rectangular to tongue-shaped with a straight or slightly rounded dorsal margin and a comma-shaped foramen (Fig. 3J). An apical attachment pore was never observed.

The first apical plate was rhomboidal and contacted po directly. Invariably, from all observed specimens $(n>50)$, there was a prominent ventral pore midway on the anterior right margin of Plate $1^{\prime}$ (Fig. 3C, D, G-I). The other apical plates were similar in size; the dorsal Plate $3^{\prime}$ was almost symmetrical (Fig. 3D). The last precingular Plate $6^{\prime \prime}$ was generally wide, with a length/width ratio of about 1 , but (rarely) this plate could be either longer than wide or wider than long (Fig. 3G-I). On the hypotheca, Plate $2^{\prime \prime \prime \prime}$ was large and wider than long (Fig. 3F). The first antapical plate bore a small list on its right side running along its sutures with the sulcal plates, but no such list was detectable as a right delimitation of the sulcus (Fig. 3F). In total nine sulcal plates (Fig. 3E) were identified, with the smallest and triangular anterior accessory platelet (saca) being relatively large and easy to detect. The anterior sulcal plate was as long as wide with a straight or slightly rippled margin contacting the posterior side of Plate $1^{\prime}$ (Fig. $3 \mathrm{~K}, \mathrm{~L}$ ). The posterior sulcal plate was wider than long (Fig. 3F, M, N) and never contained an attachment pore. The anterior margin was subdivided into two rounded dents representing the borders with the left and right posterior sulcal plates. The posterior margin was mainly triangularly pointed or had a more rectangular shape with a rounded outline (Fig. 3M, N).

\subsection{Phylogenetic associations}

Maximum likelihood analyses of LSU rDNA sequences of Alexandrium isolates from the west coast of Greenland, identified as morphologically consistent with descriptions of $A$. tamarense sensu Balech (1995), confirmed that these isolates are indeed members of the A. tamarense species complex (Fig. 4). All such isolates belong to the same ribotype/species, i.e., Group I (or known as the North American ribotype). All five clades of the A. tamarense species complex received high bootstrap support and the divergence pattern of the clades was well resolved with relatively low variation within each clade, compared to variation among the five clades. The position of Group I as sister to Group III (or Mediterranean ribotype) was also supported. Among the LSU rDNA sequences obtained from the 22 isolates, 18 variants were identified by differences in at least one nucleotide position. Most sequence variants were found in only one of the clonal isolates, whereas two sequences were found in three isolates each. The

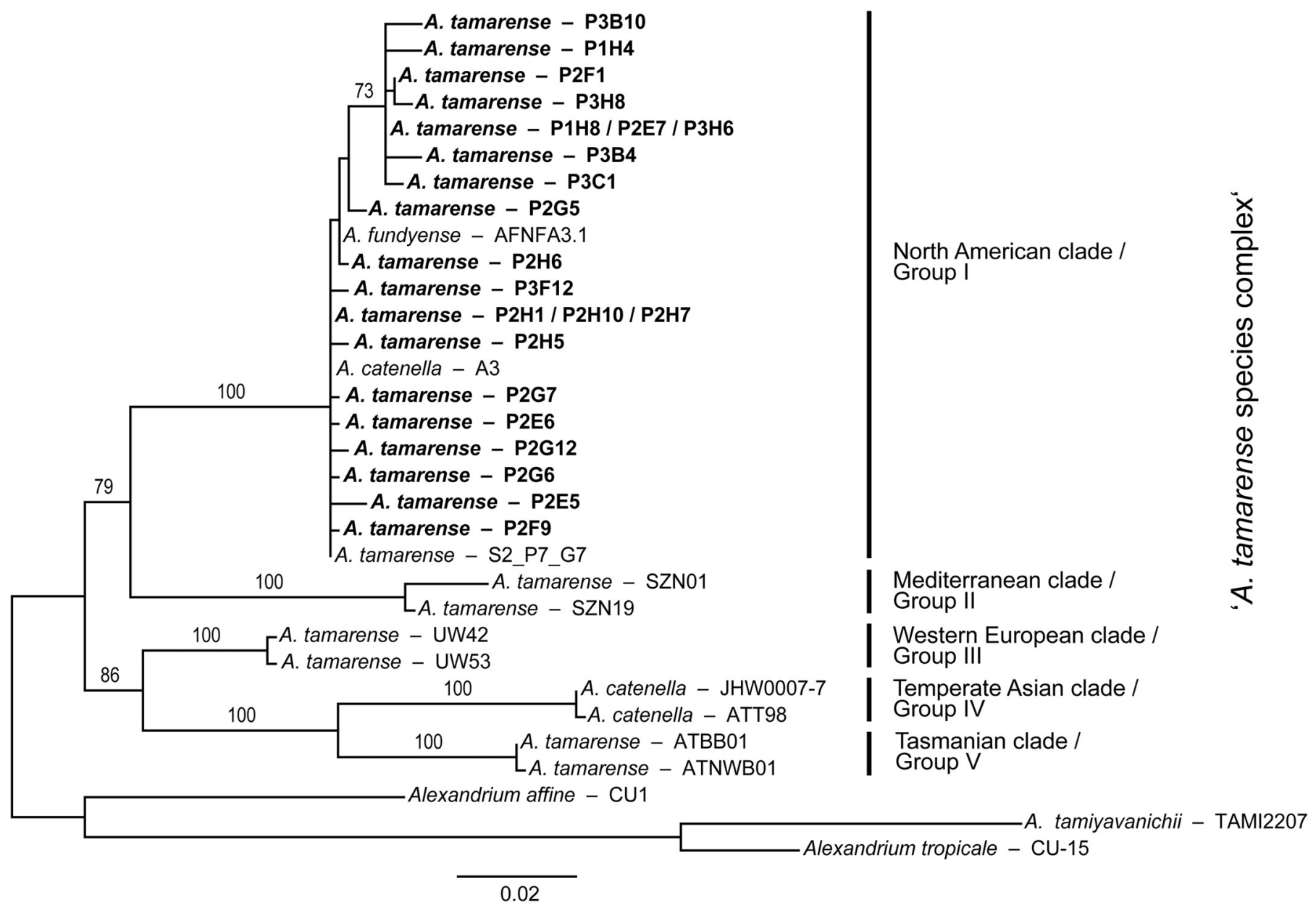

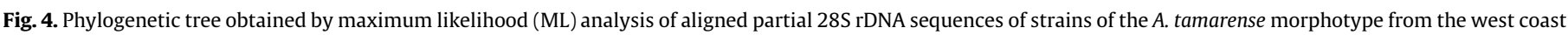

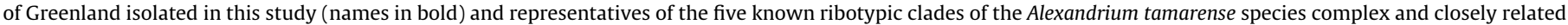

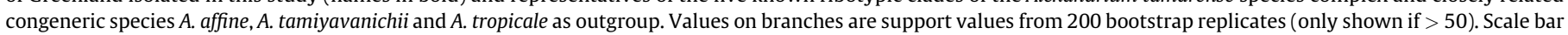
at the bottom represents average number of nucleotide substitutions. 


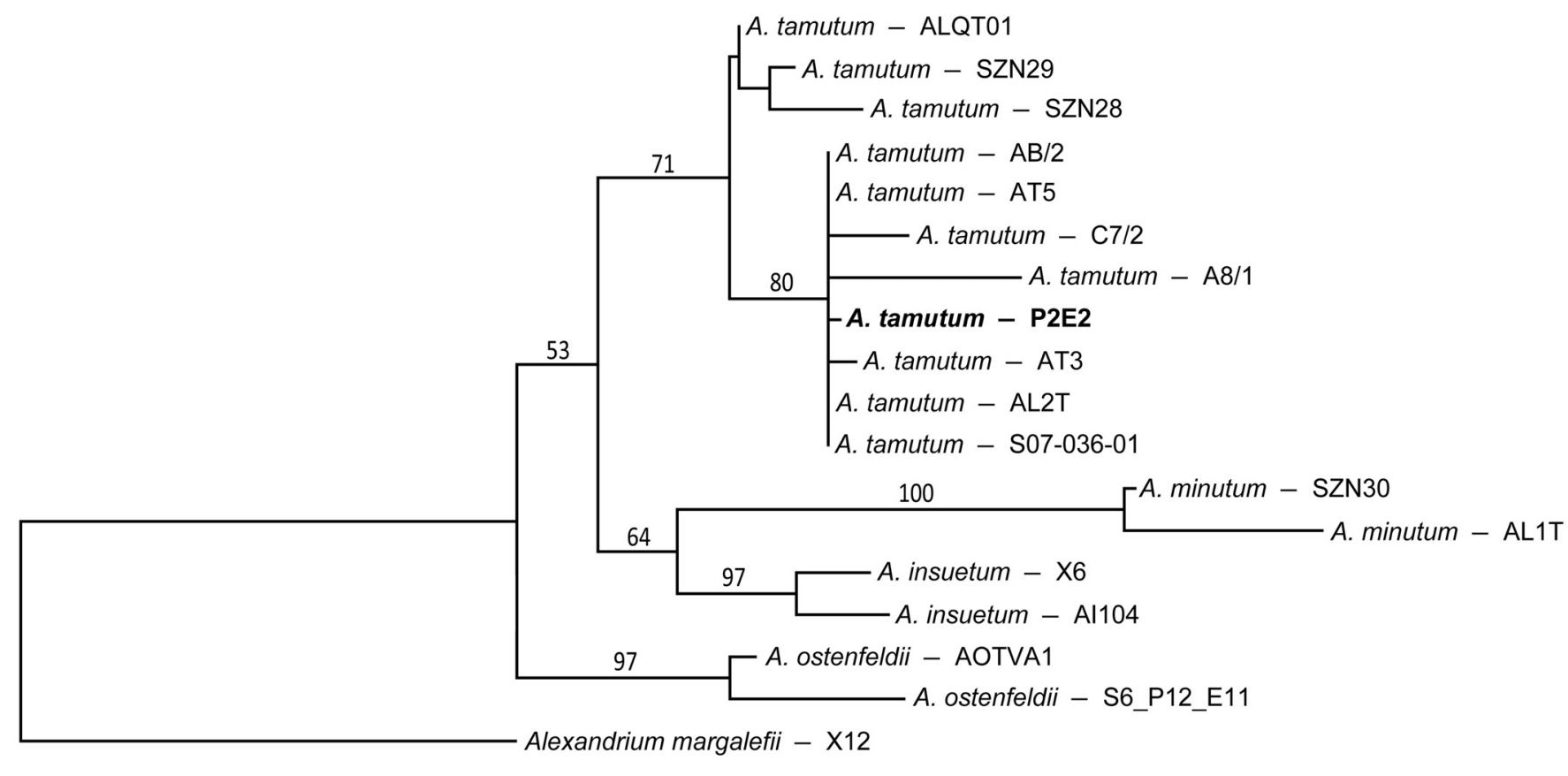

0.02

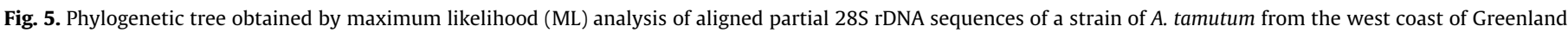

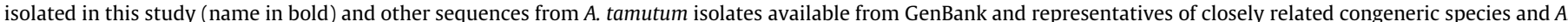

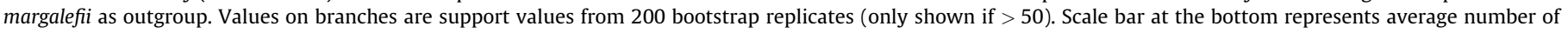
nucleotide substitutions.

extent of sequence variation within isolates, however, was not assessed.

The ML tree constructed from the alignment containing sequences of Alexandrium tamutum and closely related congeners showed that the LSU rDNA sequence from the Arctic isolate P2E2 fell within the clade comprising all other A. tamutum (Fig. 5). This clade was sister to a clade composed of Alexandrium minutum and A. insuetum; the pattern of divergence among the closely related species, however, was only weakly to moderately well supported by bootstrapped analyses. Within the A. tamutum clade, a subdivision into two subclades was adumbrated by the moderately supported ( $80 \%$ bootstrap) sub-clades that contained eight of the 13 unique isolates of $A$. tamutum included in the phylogenetic analysis (Fig. 5). The other sub-clade, however, was not even weakly supported because of its less pronounced divergence from closely related congeners at about ten nucleotide positions where identical bases were shared with some congeners from sister clades, but not with their conspecifics.

\subsection{Toxin composition and cell content}

All cultured isolates conforming to Alexandrium tamarense Group I by morphological and molecular genetic criteria produced paralytic shellfish toxins (PSTs), but no toxins were detected in Alexandrium tamutum P2E2. Cellular detection limits for PSTs quantified by the post-column derivatization method vary widely depending upon the composition of individual analogs, ranging from 0.58 (dcGTX3) to 40.8 (GTX1) fg cell ${ }^{-1}$ for the A. tamutum sample under the current operating conditions. Cell quota of PSTs was highly variable among the different $A$. tamarense Group I isolates, ranging from 4.1 to $159.3 \mathrm{pg} \mathrm{cell}^{-1}$ (Table 1 ).

Only carbamoyl toxins were detected among the 22 isolates of A. tamarense Group I; decarbamoyl and sulfocarbamoyl derivatives were absent from all isolates. The suite of carbamoyl toxins present included gonyautoxins (GTXs), neosaxtoxin (NEO) and saxitoxin
(STX) (Fig. 6), but the relative composition of these structural groups of toxins varied considerably. The relative content (weight $\%$ ) of GTX1/4 varied from 5 to $92 \%$, GTX2/3 from 1 to $50 \%$, NEO from 1 to $7 \%$ and STX from 0.5 to $68 \%$ among isolates. The $\mathrm{N}-1$ hydroxylanalog NEO was consistently present in low relative abundance ( $<7 \%$ of total PST content), whereas other PSTs varied widely from $<10 \%$ to $>50 \%$.

A similar profile, indicating the dominance of carbamoyl analogues, was found in plankton samples from the four stations of the expedition transect where PSTs were unambiguously detected above the limit of detection (LOD), but the PST profiles

Table 1

Paralytic shellfish toxin (PST) cell quota $\left(\mathrm{pg} \mathrm{cell}^{-1}\right)$ of all 22 Greenland isolates of $A$. tamarense (Group I ribotype).

\begin{tabular}{lc}
\hline Isolate & PST cell quota $\left(\right.$ pg cell $\left.^{-1}\right)$ \\
\hline P1H4 & 159.3 \\
P1H8 & 36.0 \\
P2E5 & 42.6 \\
P2E6 & 37.3 \\
P2E7 & 4.1 \\
P2F1 & 25.5 \\
P2F9 & 36.6 \\
P2G12 & 35.4 \\
P2G5 & 63.9 \\
P2G6 & 39.6 \\
P2G7 & 72.0 \\
P2H1 & 56.3 \\
P2H10 & 29.6 \\
P2H5 & 57.4 \\
P2H6 & 41.6 \\
P2H7 & 43.2 \\
P3B10 & 17.0 \\
P3B4 & 50.6 \\
P3C1 & 49.9 \\
P3F12 & 84.3 \\
P3H6 & 55.2 \\
P3H8 & 46.3 \\
\hline
\end{tabular}




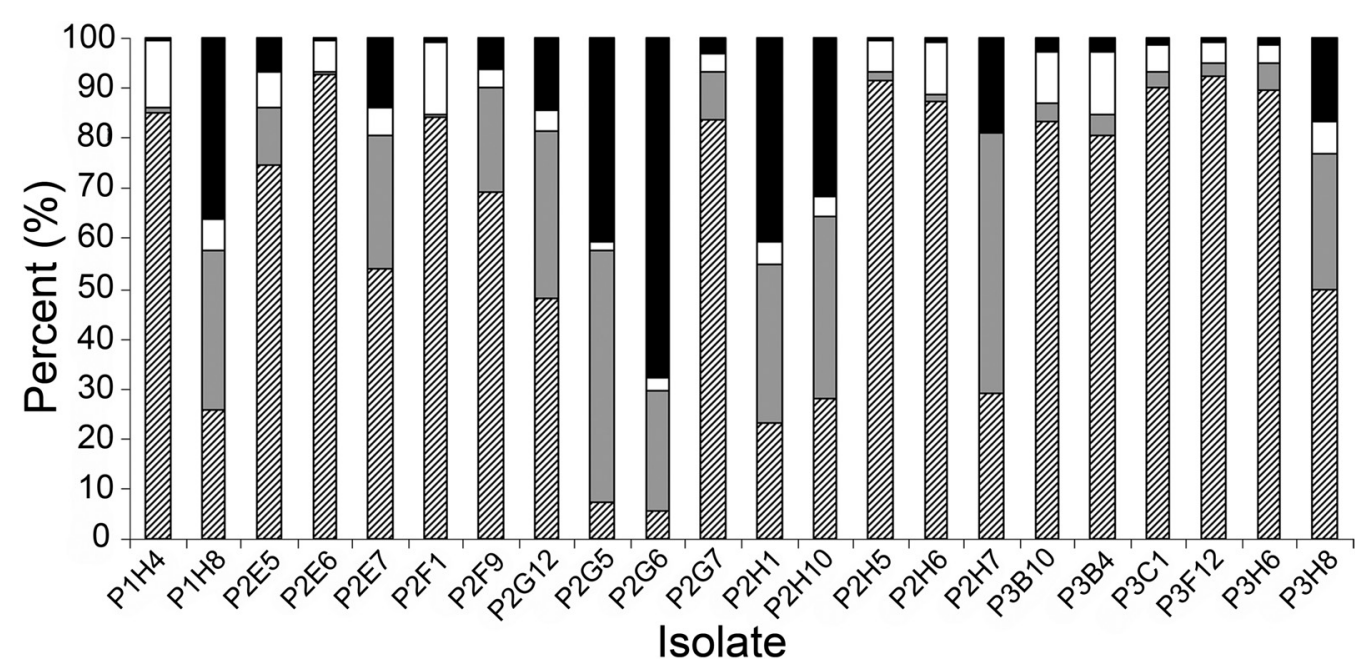

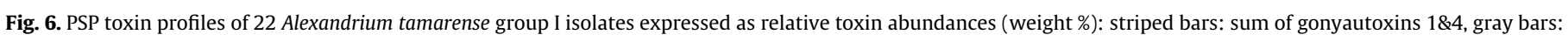
sum of gonyautoxins $2 \& 3$, white bars: neosaxitoxin, black bars: saxitoxin.

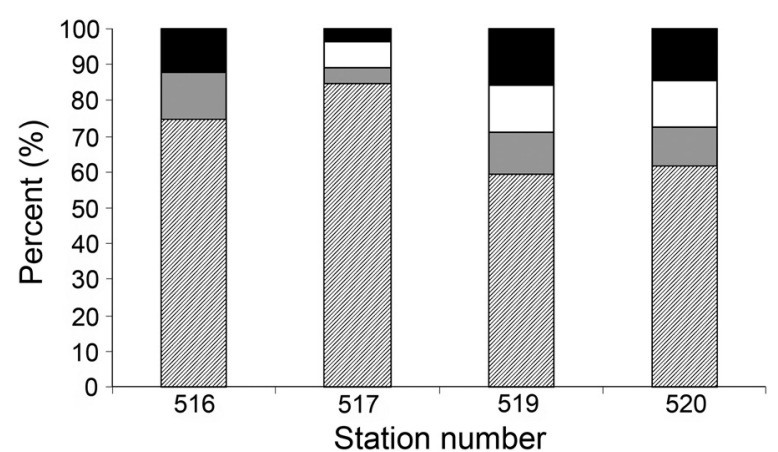

Fig. 7. PSP toxin profiles expressed as relative toxin abundances (weight \%) of plankton samples at four field sites: striped bars: sum of gonyautoxins 1 and 4 , gray bars: sum of gonyautoxins 2 and 3, white bars: neosaxitoxin, black bars: saxitoxin.

were more homogenous than those for the isolates (Fig. 7), thereby reflecting an integration of clonal toxin profiles within the population. Among field plankton samples, GTX1/4 constituted between 60 and $85 \%$ of the composition (weight \%), whereas GTX2/ 3 varied between 3 and 12\%, NEO between 0 and 11\% and STX between 3 and $16 \%$ of total PST content. The PST concentrations per net tow at these four stations ranged from $181 \mathrm{ng}$ at station 517 to $634 \mathrm{ng}$ at station 519). No PSTs, or only trace levels near the LOD, were found at other stations along the expedition transect.

\subsection{Lytic activity of cultured Alexandrium isolates}

With one exception (see below), all isolates of Alexandrium tamarense Group I and A. tamutum clearly had the demonstrated capacity to lyse the target cells of Rhodomonas salina at a given threshold cell concentration (Fig. 8). Lytic activity was expressed at a screening concentration of approximately 1000 cells $\mathrm{mL}^{-1}$ (estimated concentration of Alexandrium cells in the assay ranged from 750 to 1100 cells $\mathrm{mL}^{-1}$; mean for all isolates: $931 \pm 92 \mathrm{SD}$ cells $\mathrm{mL}^{-1}$ ). In all bioassay trials, positive controls with the known lytic A. tamarense Group I strain Alex2 yielded total lysis of Rhodomonas cells, whereas negative control trials with the non-lytic strain Alex5 were not significantly different from seawater controls (data not shown). At the fixed dose of $\mathrm{ca}$. 1000 cells $\mathrm{mL}^{-1}$, lytic capacity varied considerably among Alexandrium isolates, with the final percentage of intact Rhodomonas cells ranging from 0 to $96.1 \%$. Terminal Rhodomonas cell concentrations after incubation with Alexandrium isolate P2G5 at the specific cell concentration was not significantly different ( $t$-test of significance of means, $p=0.15, n=3$ )

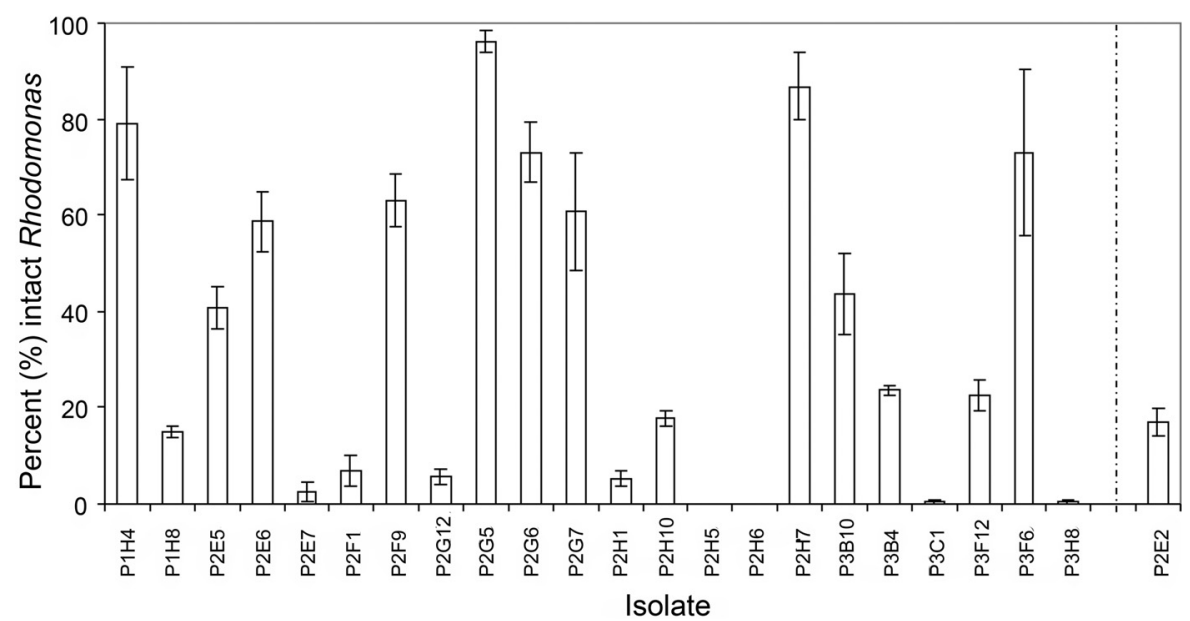

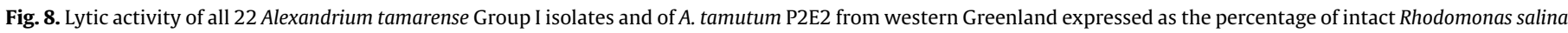
cells compared to the seawater control. Bars represent the mean of technical triplicates with \pm 1 SD as error bars. 
from the control, hence were judged "negative" for lytic activity. Nevertheless, an additional test of isolate P2G5 at a distinctly higher dose ( $c a .3000$ cells $\mathrm{mL}^{-1}$ ) clearly showed that this isolate was lytic as well (result not shown).

\section{Discussion}

Knowledge of the phylogenetic and biogeographical aspects of the distribution of Alexandrium genotypes in Arctic waters remains preliminary and incomplete due to the paucity of valid probing of in situ natural populations and cultured isolates derived from these assemblages. From a morphological perspective, examination of thecal plate details of the current Alexandium isolates from western Greenland allowed an unambiguous distinction between and a clear assignment of the isolates to either the A. tamarense morphotype or to A. tamutum. As pointed out by Montresor et al. (2004), the shape of the posterior sulcal plate is the most distinctive and useful morphological feature to separate these species, which are otherwise very similar. The presence/absence of a ventral pore has been one of the morphological traits used to distinguish A. tamarense and Alexandrium fundyense (Balech, 1995). However, the taxonomic significance of this feature for species of Alexandrium has been questioned since strains with a ventral pore (A. tamarense) and without a ventral pore (A. fundyense) are grouped within the same ribotype clade (Anderson et al., 2012). Moreover, the ventral pore of Alexandrium was found to be a slightly variable feature in clonal isolates or field populations (Anderson et al., 1994; Kim et al., 2002; Hansen et al., 2003). Nevertheless, despite some variability in the size of the ventral pore, all cells of all Greenland A. tamarense isolates had such a pore, which is in agreement with the Greenland isolates examined by Baggesen et al. (2012).

Based upon extensive observation of field specimens, Balech (1995) had previously noted that Alexandrium tamarense is one of the most morphologically variable species within the genus. In the present study, overall cell size and shape, as well as the shape of some thecal plates, was found to be quite variable among cells within clonal isolates. Furthermore, this variability is in accordance with the known degree of morphological variation within and among cultured isolates and among vegetative cells of natural Alexandrium populations from the east coast of Russia (Orlova et al., 2007). With a mean apical/trans-apical diameter (or length $[\mathrm{L}] /$ width $[\mathrm{W}]$ ) ratio of slightly $\leq 1$, the present isolates were distinctly more spherical than those reported on by Baggesen et al. (2012), with a L/W ratio of 1.13-1.2. Moreover, in contrast to the low cell-size variation within Greenland isolates as previously reported, cells of the present isolates ranged by up to two-fold in cell length. Although such large differences in cell size might indicate the presence of different life cycle stages (vegetative cells, gametes, or planozygotes), this is unlikely within a (probably heterothallic) clonal culture (Destombe and Cembella, 1990). Furthermore, there was not any direct evidence of sexual reproduction, such as gamete fusion or resting cyst formation in the cultures. More likely, such cell size and minor thecal plate variations reflect small inhomogeneities in growth rate and mitotic cell division among cells grown under culture conditions.

In any case, a few provisional inferences can be drawn from the emerging data from the western Greenland Coast. First, the genotypes represented by the Greenland isolates are consistent with and not disjunct from clades described from north temperate waters. All isolates of the Alexandrium tamarense morphotype from Greenland belong to the same ribotype/species, i.e., Group I (formerly North American ribotype). This ribotype is dominant in cold temperate waters of the eastern and western North Atlantic, and includes representative isolates such as S2_P7_G7 from the
North Sea off the Scottish coast (Alpermann et al., 2010) and AFNFA3.1 from Newfoundland (Scholin et al., 1994), respectively.

The phylogenetic analysis of isolates of Alexandrium tamarense from west Greenland confirmed herein their membership with the Group I (or North American ribotype) of the species complex. Only recently an integrative taxonomic approach has been undertaken to resolve taxonomic issues within the $A$. tamarense species complex (John et al., 2014). These authors formulated species hypotheses consistent with the five distinct ribosomal clades within the A. tamarense species complex and reassigned existing species names. Following this interpretation, many clonal isolates and natural populations from North Atlantic and North Sea waters, formerly assigned to A. tamarense (and earlier Protogonyaulax tamarense and P. excavatum) would be re-assigned to Alexandrium catenella (this is the senior synonym which has priority (Fraga et al., 2015) over the Alexandrium fundyense proposed by John et al., 2014). This also implies that the Greenland isolates and natural populations considered herein would be dubbed A. catenella and that representative of most populations previously considered to be of A. tamarense from the Scottish coast (Alpermann et al., 2010), west Greenland (Baggesen et al., 2012) and many other North Atlantic locations should be retroactively considered for renaming. While the current data are not inconsistent with such a rearrangement, this remains a taxonomic and nomenclatural issue and is not central to the argument of the biogeographical and phylogenetic affinities exhibited by the Greenland populations. Importantly, the recent evidence is entirely consistent with the previous consideration of three isolates of the $A$. tamarense species complex originating from the west coast of Greenland within Disko Bay (Baggesen et al., 2012), near the sampling station of isolates analyzed in the current study. The previous isolates were also of the $A$. tamarense morphotype, and included the presence of a ventral pore at the margin of the first apical ( $\left.1^{\prime}\right)$ plate. Furthermore, these isolates all belonged to the same ribotype/species, i.e., Group I, based on criteria of the LSU rDNA sequences (Baggesen et al., 2012).

Although a firm conclusion would require analysis of a much larger number of clonal isolates of the Alexandrium tamarense morphotype than are presently available, evidence suggests that Group I might either be the only or at least the widely dominant ribotype/species along the west coast of Greenland. Whether or not this ribotype/species dominates throughout the Arctic remains an open question, largely due to the lack of molecular evidence. For example, the toxigenic natural populations of the Alexandrium tamarense complex found in Icelandic fjords were assigned to $A$. tamarense based upon microscopic observation of cells by the Utermöhl method, but no molecular data on ribotyping were provided (Burrell et al., 2013). Confirmation of the presence or absence of alternative ribotypes of this species complex in the Arctic might be more comprehensively investigated by additional screenings of planktonic cells by various molecular probe-based methods, such as in situ hybridization (e.g. John et al., 2005) or recently developed ribotype-specific real time-quantitative PCR (RT-qPCR) techniques (e.g. Toebe et al., 2013).

In comparison to members of the Alexandrium tamarense species complex, the distribution of Alexandrium tamutum is much less well understood. Originally believed to be restricted to the Mediterranean, followed later by reports from the North Sea, its biogeographical distribution proved to have been underestimated to date. This may be an artefact of inadequate identification because $A$. tamutum has only been recognized as a distinct morphospecies for just over a decade, and requires critical observation for discrimination from other Alexandrium species. The fact that all known cultured strains and natural populations are found to be non-toxigenic may also have diminished awareness of its relative contribution to the plankton. Hence here the first 
identification of this species in the Arctic is reported. The ML tree of isolates of A. tamutum containing strain P2E2 established from waters off the west coast of Greenland showed that $28 \mathrm{~S}$ ribosomal DNA sequences formed a monophyletic clade with moderately strong support. A pronounced subdivision within this clade was not found, although some indication of genetic divergence was evident from the moderately well supported subclade into which the isolate from Greenland was placed. A more thorough analysis of genetic divergence based upon a number of nuclear markers, such as microsatellites or amplified fragment length polymorphism (AFLP), might reveal a more pronounced genetic divergence within A. tamutum on the population level. Such patterns have already been found for other species of the genus, such as $A$. tamarense Group I/North American ribotype (Nagai et al., 2007) or Alexandrium ostenfeldii (Tahvanainen et al., 2012), respectively.

\subsection{PSP toxins}

An indication of the presence and abundance of the members of the PSP-toxigenic Group I/North America ribotype of Alexandrium tamarense along the west coast of Greenland may be gleaned from the compositional profile and content distribution of PSP toxins in plankton samples collected during oceanographic expeditions, such as the present study. Nonetheless, PSTs were only rarely detected throughout the entire expedition transect. PST levels exceeding by several-fold the limit of detection (LOD) were found only at the entrance to Disko Bay and occasionally along the Greenland west coast between 66 and $69{ }^{\circ} \mathrm{N}$. In all cases, PST levels were consistently low in plankton net tows (NT), with a maximum value of $634 \mathrm{ng} \mathrm{NT}^{-1}$.

The theoretical water volume sampled by phytoplankton net hauls can easily be calculated. Net hauls are not regarded as reliable quantitative estimates of plankton biomass or ambient cell concentrations along the vertical axis through the water column, but can nevertheless provide crude estimates for consideration. In the present case, the theoretical value is $3700 \mathrm{~L}$ seawater filtered (at $>20 \mu \mathrm{m}$ ) from $30 \mathrm{~m}$ depth to surface. Assuming complete toxin recovery in the particulate fraction, that the toxin is homogeneously distributed over the upper $30 \mathrm{~m}$ of the water column, and that all detectable toxin can be associated with Alexandrium cells, would yield an estimated PST concentration of $171 \mathrm{pg} \mathrm{L}^{-1}$ seawater at station 519 with the highest value. Although the foregoing criteria are not strictly valid, a realistic mean PST cell quota of $50 \mathrm{pg} \mathrm{cell}^{-1}$, would imply a mean Alexandrium cell abundance in the upper water column in the order of magnitude of approximately 6 cells $\mathrm{L}^{-1}$. Even with plankton counts indicating slightly higher concentrations of

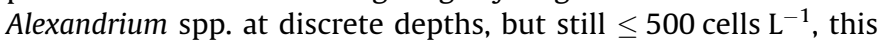
indicates that no high magnitude Alexandrium blooms of toxigenic ribotypes were sampled during the expedition.

The toxin profiles of Alexandrium tamarense Group I isolated from the west coast of Greenland are consistent with those of the same species previously isolated from Attu and Maniitsoq, Greenland (Baggesen et al., 2012), which also only consisted of the carbamoyl toxins GTX1/4, GTX2/3, NEO and STX. Furthermore, the relative molar abundances of these carbamoyl analogs in previous isolates from western Greenland generally reflect those of the isolates from the present study, with GTX1/4 typically the most abundant toxins. Genetically determined intra-population toxin variability is more evident in the present study, e.g., a few isolates demonstrated a higher relative NEO content than GTX1/4, likely a reflection of the greater number of clones examined than in the previous comparison of clones from western Greenland $(n=3)$ (Baggesen et al., 2012). This does not alter the basic fact that $A$. tamarense from western Greenland seems to produce only four distinct PSTs, namely GTX2/3, GTX1/4, NEO and STX-a classic toxin profile of the Alexandrium minutum species complex (Cembella et al., 1987), including the likely conspecifics Alexandrium ibericum and Alexandrium angustitabulatum, the latter exclusively reported from New Zealand.

These findings are surprising in the sense that the Alexandrium tamarense species complex typically produces high molar relative amounts of the $\mathrm{N}$-sulfocarbamoyl B- and C-toxins in natural populations and cultured isolates from many regions of the world (Cembella, 1998), including the south Atlantic (Montoya et al., 2010), north Atlantic and North Sea (Brown et al., 2010), south Pacific (Contreras et al., 2012), and the northeastern (Gu et al., 2013a) and northwestern (Cembella et al., 1987) Pacific. This general pattern is also consistent within A. tamarense Group I ribotype strains from the western Arctic (Chukchi Sea), where the $\mathrm{N}$-sulfocarbamoyl toxin C2 dominated, followed by STX and GTX2/ 3 , with lesser amounts of GTX1/4 and NEO in decreasing relative molar ratios (Gu et al., 2013b). In contrast, natural populations of the $A$. tamarense group in Icelandic fjords yielded dominance by the carbamoyl toxins, with GTX2/3 $>$ STX $>$ GTX1/4 in decreasing order of relative abundance, and the absence of N-sulfocarbamoyl toxins and NEO (Burrell et al., 2013). Populations from highly diverse locations along the eastern Russian coast, including Arcticadjacent waters of the Bering Sea, were highly variable in toxin profile, but consistently contained significant (often dominant) proportions of N-sulfocarbamoyl toxins, particularly C2 or B1 (=GTX5) (Orlova et al., 2007).

Although they can be determined independently by either LCFD or tandem mass spectrometry (LC-MS/MS), little significance should be assigned to the relative molar ratios of GTX1/GTX4 and GTX2/GTX3 analyzed from dinoflagellates. Dinoflagellates are believed to biosynthesize only the $\beta$-epimers (e.g., GTX4, GTX3) of the 11-sulfated gonyautoxins (Cembella, 1998), but these are subject to facile epimerization from $\beta$ - to $\alpha$-epimers (e.g., GTX1, GTX2) and thermodynamic equilibration, particularly under extreme $\mathrm{pH}$ and at elevated temperature. As a consequence, significant levels of $\alpha$-epimers can almost always be detected in PST-containing plankton samples. Due to the ready interconversion of the enantiomers and instability in the epimeric ratios, these are here only reported as the sum of the epimeric pairs and for comparison with other literature reports of toxin profiles. The fact that in the plankton samples the relative concentration of $\alpha$ epimers never exceeded $5 \%$ of the sum of the enantiomeric pairs (data not shown) provides strong evidence that $\beta$-epimers are exclusively synthesized by the dinoflagellates and that the presence of $\alpha$-epimers can be attributed to sample processing artefacts.

Comparing of toxin cell quota, or molar amount of toxin per cell, has been previously invoked to define Alexandrium populations as high, medium or low toxicity (e.g., Cembella et al., 1987; Anderson et al., 1994), but such analyses are complicated by high intrapopulation variability, toxin content variation over the culture cycle, discrepancies in comparing cultured isolates with natural populations, and the application of alternative analytical methods to determine cell toxin composition (Cembella, 1998). The cell toxin content is a much more unstable phenotypic characteristic than is the toxin compositional profile. Nevertheless, it is instructive to note that toxin content of Alexandrium tamarense isolates from the Chuckchi Sea (range: 9-41 $\left.\mathrm{fmol} \mathrm{cell}^{-1} ; n=4\right)(\mathrm{Gu}$ et al., 2013b) overlaps more or less with that of cultured isolates from populations from the Russian east coast (Bering Sea, Sea of Okhotsk, and Sea of Japan; range: $31-171 \mathrm{fmol} \mathrm{cell}^{-1} ; n=27$ ) (Orlova et al., 2007). Taking into consideration the differences in toxin profile, i.e. dominance by the carbamoyl derivatives, an estimate of the range of molar toxin content per cell among the west coast Greenland isolates $(n=22)$ of $1-50 \mathrm{fmol} \mathrm{cell}^{-1}$ (converted from Table 1) shows them to be similar to those of other 
populations from the Arctic and North Pacific waters, with the anomalous exception of the low toxin content for isolate P2E7.

\subsection{Lytic activity}

Putative ecological roles for the production and release of allelochemical substances have been widely and controversially discussed (e.g. Smayda, 1997; Cembella, 2003; Tillmann, 2004; Jonsson et al., 2009), particularly for known toxigenic species. Among Alexandrium species, interspecific competition and antipredation defense mechanisms are most frequently invoked. All isolates of Alexandrium tamarense Group I from Greenland produce allelochemicals (distinct from PST) with the capacity to lyse cells of the target species Rhodomonas. Lytic activity of extracellular secondary metabolites is rather widespread among the genus Alexandrium and has been verified for a number of different species (Tillmann and John, 2002; Tillmann et al., 2008). Here it is shown for the first time that Alexandrium tamutum is also capable of producing lytic allelochemicals. Generally, allelochemical activity of Alexandrium spp. has been shown to affect membrane integrity, mobility via loss of flagella and/or cell survival against a wide variety of other microalgae (Arzul et al., 1999; Tillmann et al., 2008; Tillmann and Hansen, 2009), heterotrophic protists (Hansen et al., 1992; Matsuoka et al., 2000; Tillmann and John, 2002) and diverse members of microbial communities (Weissbach et al., 2011). Although molecular structures and exact mode of action of allelochemicals from Alexandrium still are poorly known (Ma et al., 2009; Ma et al., 2011), all evidence suggest that the lytic activity against target protists is not related to the known toxins, such as saxitoxins and spirolides, produced among members of this genus (Tillmann and John, 2002; Tillmann et al., 2007).

A simple one-concentration bioassay was used to show lytic activity and yet there are no full dose-response curves that are needed to estimate $\mathrm{EC}_{50}$ values, i.e. the cell concentration of Alexandrium causing lysis of $50 \%$ of the Rhodomonas cell population. Nevertheless, the data show that $\mathrm{EC}_{50}$ values of most Greenland isolates grown at $10{ }^{\circ} \mathrm{C}$ are well below 1000 cells $\mathrm{mL}^{-1}$. This threshold lies well within the range of $\mathrm{EC}_{50}$ values estimated for lytic isolates of Alexandrium from temperate waters, which range from 80 to 640 cells $\mathrm{mL}^{-1}$ (Tillmann et al., 2009).

The screening also indicates that there are profound quantitative differences in lytic activity among different isolates. However, it has to be kept in mind that although the isolates were grown under exactly the same environmental conditions, and harvested during exponential growth, they were not rigorously sampled at a definitive growth stage, i.e., after an equivalent number of cell divisions. Difference in specific growth rate could therefore have contributed to the observed differences. Quantitative differences in lytic activity were also found among isolates from within a geographical population of Alexandrium tamarense from the western North Sea (Alpermann et al., 2010). The intrinsic variability among North Sea isolates with respect to lytic capacity was not apparently coupled to the cell content or composition of PST analogues. Nevertheless, in contrast to the Greenland isolates, which express a unique and consistent PST phenotype, the North Sea populations exhibit a high diversity of toxin compositional profiles, presumably reflecting variability in the set of genes that mediate interconversion of saxitoxin derivatives/or in transcriptional regulatory functions.

Cell concentrations causing the lytic effects used in this study were roughly four orders of magnitude above the densities of Alexandrium spp. estimated in the field samples during the present field expedition. However, motile phytoplankton, such as Alexandrium spp., may accumulate in horizontal layers under certain conditions, along thermoclines or the water surface (MacIntyre et al., 1997; Mouritsen and Richardson, 2003) and the resulting high densities at the microscale may be accompanied by effective concentrations of secondary metabolites in these layers.

Moreover, lytic compounds produced by Alexandrium may be involved in cell-to-cell interactions and thus would be independent in their effect from the cell density. A number of allelochemically active microalgae, including species of Alexandrium and Fragilidium, have been shown to be mixotrophic (Jacobson and Anderson, 1986; Tillmann, 1998; Jeong et al., 2005; Stoecker et al., 2006; Yoo et al., 2009; Sheng et al., 2010; Blossom et al., 2012) and it has been speculated that allelochemicals can be deployed for predation. In the present experiments, however phagotrophic uptake of Rhodomonas by Alexandrium was not observed.

In conclusion, it was demonstrated in this limited regional Arctic study that taxonomic and phylogenetic associations of populations within the Alexandrium tamarense species complex conform primarily to the morphological and molecular characteristics of the Group I (formerly North American ribotype). However, the genetically fixed unique PSP toxin profile of Greenland isolates, which does not resemble that of any other members of the $A$. tamarense species complex, but rather that of Alexandrium minutum, is curious and has two-fold implications. First, it provides preliminary evidence of the independent acquisition, evolution, and/or expression of the set of genes that mediate interconversion of saxitoxin derivatives in these Arctic populations. Second, this has important implications for the interpretation of biogeographical patterns of hypothetical Alexandrium bloom dispersal between the Pacific and Atlantic, with the Arctic Ocean as the gateway via the Davis Strait and Baffin Bay. Evidence of an autochthonous population of Group I/North American ribotype in the Disko Bay makes it unlikely that dispersal or range extension of this species has taken place via this route in recent times, as no signatures of such dispersal could be deduced from the unique toxin profiles of the isolates analyzed herein. These biomarkers therefore indicate very low intra-specific linkages (if any) between Greenland populations and the coastal Alexandrium populations of Newfoundland and Labrador and the Gulf of St Lawrence. Refined analysis of population connectivity among geographically separated populations of this species, e.g., by application of highly polymorphic molecular markers such a DNA microsatellites, will certainly further our understanding of the evolutionary ecological position of western Greenland populations of $A$. tamarense within the globally distributed Group I/North American ribotype. Such improved understanding will be key for constructing reliable hindcast scenarios and for predicting changes in toxic Alexandrium species distribution from the regional Arctic to the global scale under scenarios of future climatic change.

\section{Acknowledgements}

We greatly acknowledge the help of Annegret Müller (AWI) for analyses of PSP toxins. We thank Nancy Kühne (AWI) for DNA extraction and sequencing of the Alexandrium clones. Captain Bergmann and the crew of the FS Maria S. Merian provided essential assistance and support for the collection of field material. The oceanographic cruise was conducted as a contribution to the SCOR/ IOC GEOHAB Core Research Project on HABs in Fjords and Coastal Embayments. Financial support was provided by the PACES research program of the Alfred Wegener Institute as part of the Helmholtz Foundation initiative in Earth and Environment.[SS]

\section{Appendix A. Supplementary data}

Supplementary data associated with this article can be found, in the online version, at doi:10.1016/j.hal.2015.11.004. 


\section{References}

Alpermann, T.J., Tillmann, U., Beszteri, B., Cembella, A.D., John, U., 2010. Phenotypic variation and genotypic diversity in a planktonic population of the toxigenic marine dinoflagellate Alexandrium tamarense (Dinophyceae). J. Phycol. 46, $18-32$.

Anderson, D.M., Kulis, D.M., Doucette, G.J., Gallagher, J.C., Balech, E., 1994. Biogeography of toxic dinoflagellates in the genus Alexandrium from the northeastern United States and Canada. Mar. Biol. 120, 467-478.

Anderson, D.M., Alpermann, T.J., Cembella, A.D., Collos, Y., Masseret, E., Montresor, M., 2012. The globally distributed genus Alexandrium: Multifaceted roles in marine ecosystems and impacts on human health. Harmful Algae 14, $10-35$.

Arzul, G., Seguel, M., Guzman, L., Erard-LeDenn, E., 1999. Comparison of allelopathic properties in three toxic Alexandrium species. J. Exp. Mar. Biol. Ecol. 232, 285-295.

Baggesen, C., Moestrup, Ø., Daugbjerg, N., Krock, B., Cembella, A.D., Madsen, S., 2012. Molecular phylogeny and toxin profiles of Alexandrium tamarense (Lebour) Balech (Dinophyceae) from the west coast of Greenland. Harmful Algae 19, $108-116$.

Balech, E., 1995. The Genus Alexandrium Halim (Dinoflagellata). Sherkin Island Marine Station Publication, Sherkin Island, Co, Cork, Ireland.

Blossom, H., Daugbjerg, N., Hansen, P.J., 2012. Toxic mucus traps: A novel mechanism that mediates prey uptake in the mixotrophic dinoflagellate Alexandrium pseudogonyaulax. Harmful Algae 17, 40-53.

Brown, L., Bresnan, E., Graham, J., Lacaze, J.P., Turrell, E., Collins, C., 2010. Distribution, diversity and toxin composition of the genus Alexandrium (Dinophyceae) in Scottish waters. Eur. J. Phycol. 45, 375-393.

Burrell, S., Gunnarsson, T., Gunnarsson, K., Clarke, D., Turner, A.D., 2013. First detection of paralytic shellfish poisoning (PSP) toxins in Icelandic mussels (Mytilus edulis): Links to causative phytoplankton species. Food Control 31, 295-301.

Bursa, A.S., 1961. The annual oceanographic cycle at Igloolik in the Canadian Arctic. II. The phytoplankton. J. Fish. Res. Bd. Can. 18, 563-615.

Cembella, A., Taylor, F.J.R., Therriault, J.C., 1988. Cladistic analysis of electrophoretic variants within the toxic dinoflagellate genus Protogonyaulax. Bot. Mar. 31, 39-51.

Cembella, A.D., Sullivan, J.J., Boyer, G.L., Taylor, F.J.R., Andersen, R.J., 1987. Variation in paralytic shellfish toxin composition within the Protogonyaulax tamarensis/ catenella species complex. Biochem. Syst. Ecol. 15, 171-186.

Cembella, A.D., 1998. Ecophysiology and metabolism of paralytic shellfish toxins in marine microalgae. In: Anderson, D.M., Cembella, A.D., Hallegraeff, G.M. (Eds.) Physiological Ecology of Harmful Algal Blooms. Springer Verlag, Berlin, pp. 381-403.

Cembella, A.D., 2003. Chemical ecology of eukaryotic microalgae in marine ecosystems. Phycologia 42, 420-447.

Contreras, A.M., Marsden, I.D., Munro, M.H.G., 2012. Physiological effects and biotransformation of PSP toxins in the New Zealand scallop, Pecten novaezelandiae. J. Shellfish Res. 31, 1151-1159.

Destombe, C., Cembella, A.D., 1990. Mating-type determination, gametic recognition and reproductive success in Alexandrium excavatum (Gonyaulacales, Dinophyta), a red-tide dinoflagellate. Phycologia 29, 316-325

Diener, M., Erler, K., Hiller, S., Christian, B., Luckas, B., 2006. Determination of paralytic shellfish poisoning (PSP) toxins in dietary supplements by application of a new HPLC/FD method. Eur. Food Res. Technol. 224, 147-151.

Fraga, S., Sampedro, N., Larsen, J., Moestrup, Ø., Calado, A.J., 2015. Arguments against the proposal 2302 by John \& al. to reject the name Gonyaulax catenella (Alexandrium catenella). Taxon 64, 634-635.

Gu, H., Zeng, N., Liu, T., Yang, W., Müller, A., Krock, B., 2013a. Morphology, toxicity, and phylogeny of Alexandrium (Dinophyceae) species along the coast of China. Harmful Algae 27, 68-81.

Gu, H., Zeng, N., Xie, Z., Wang, D.Z., Wang, W., Yang, W., 2013b. Morphology, phylogeny, and toxicity of Atama complex (Dinophyceae) from the Chukchi Sea. Polar Biol. 36, 427-436.

Hansen, G., Daugbjerg, N., Franco, J.M., 2003. Morphology, toxin composition and LSU rDNA phylogeny of Alexandrium minutum (Dinophyceae) from Denmark, with some morphological observations on other European strains. Harmful Algae 2, 317-335.

Hansen, P.J., Cembella, A.D., Moestrup, Ø., 1992. The marine dinoflagellate Alexandrium ostenfeldii: Paralytic shellfish toxin concentration, composition, and toxicity to a tintinnid ciliate. J. Phycol. 28, 597-603.

Heimdal, B.R., 1983. Phytoplankton and nutrients in the waters north-west of Spitsbergen in the autumn of 1979. J. Plankton Res. 5, 901-918.

Horner, R.A., Garrison, D.L., Plumley, F.G., 1997. Harmful algal blooms and red tide problems on the U.S. west coast. Limnol. Oceanogr. 42, 1076-1088.

Jacobson, D.M., Anderson, D.M., 1986. Thecate heterotrophic dinoflagellates: Feeding behaviour and mechanisms. J. Phycol. 22, 249-258.

Jeong, H.J., Yoo, Y.D., Park, J.Y., Song, J.Y., Kim, S.T., Lee, S.H., Kim, K.Y., Yih, W.H. 2005. Feeding by phototrophic red-tide dinoflagellates: Five species newly revealed and six species previously known to be mixotrophic. Aquat. Microb. Ecol. 40, 133-150.

John, U., Fensome, R.A., Medlin, L.K., 2003. The application of a molecular clock based on molecular sequences and the fossil record to explain biogeographic distributions within the Alexandrium tamarense "species complex" (Dinophyceae). Mol. Biol. Evol. 20, 1015-1027.
John, U., Medlin, L.K., Groben, R., 2005. Development of specific rRNA probes to distinguish between geographic clades of the Alexandium tamarense species complex. J. Plankton Res. 27, 199-204.

John, U., Litaker, R.W., Montresor, M., Murray, S., Brosnahan, M.L., Anderson, D.M., 2014. Formal revision of the Alexandrium tamarense species complex (Dinophyceae) taxonmomy: The introduction of five species with emphasis on molecular-based (rDNA) classification. Protist 165, 779-804

Jonsson, P.R., Pavia, H., Toth, G., 2009. Formation of harmful algal blooms cannot be explained by allelopathic interactions. Proc. Natl. Acad. Sci. U. S. A. 106 $11177-11182$

Katoh, M., Kuma, M., 2002. MAFFT: A novel method for rapid multiple sequence alignment based on fast Fourier transform. Nucleic Acids Res. 30, 3059-3066.

Keller, M.D., Selvin, R.C., Claus, W., Guillard, R.R.L., 1987. Media for the culture of oceanic ultraphytoplankton. J. Phycol. 23, 633-638.

Kim, K.Y., Yoshida, M., Fukuyo, Y., Kim, H.C., 2002. Morphological observation on Alexandrium tamarense (Lebour) Balech, A catenella (Whedon et Kofoid) Balech and one related morphotype (Dinophyceae) in Korea. Algae 17, 11-19.

Konovalova, G.V., 1993. Toxic and potentially toxic dinoflagellates from the far east coastal waters of Russia. In: Smayda, T.J., Shimizu, Y. (Eds.), Toxic Phytoplankton Blooms in the Sea. Elsevier Science Publishers B.V., Amsterdam, pp. 275-279.

Krock, B., Seguel, C.G., Cembella, A.D., 2007. Toxin profile of Alexandrium catenella from the Chilean coast as determined by liquid chromatography with fluorescence detection and liquid chromatography coupled with tandem mass spectrometry. Harmful Algae 6, 734-744.

Lilly, E.L., Halanych, K.M., Anderson, D.M., 2007. Species boundaries and global biogeography of the Alexandrium tamarense species complex. J. Phycol. 43, 1329-1338.

Ma, H., Krock, B., Tillmann, U., Cembella, A., 2009. Preliminary characterization of extracellular allelochemicals of the toxic marine dinoflagellate Alexandrium tamarense using a Rhodomonas salina bioassay. Mar. Drugs 7, 497-522.

Ma, H., Krock, B., Tillmann, U., Muck, A., Wielsch, N., Svatos, A., Cembella, A., 2011. Isolation of activity and partial characterization of large non-proteinaceous lytic allelochemicals produced by the marine dinoflagellate Alexandrium tamarense. Harmful Algae 11, 65-72.

MacIntyre, J.G., Cullen, J.J., Cembella, A.D., 1997. Vertical migration, nutrition and toxicity in the dinoflagellate Alexandrium tamarense. Mar. Ecol. Prog. Ser. 148, 201-216.

Matsuoka, K., Cho, H.J., Jacobson, D.M., 2000. Observation of the feeding behaviour and growth rates of the heterotrophic dinoflagellate Polykrikos kofoidii (Polykrikaceae, Dinophyceae). Phycologia 39, 82-86.

Montoya, N.G., Fulco, V.K., Carignan, M.O., Carreto, J.I., 2010. Toxin variability in cultured and natural populations of A. tamarense from southern South America - evidences of diversity and environmental regulation. Toxicon 56, 1408-1418.

Montresor, M., John, U., Beran, A., Medlin, L.K., 2004. Alexandrium tamutum sp. nov. (Dinophyceae): A new nontoxic species in the genus Alexandrium. J. Phycol. 40, 398-411.

Mouritsen, L.T., Richardson, K., 2003. Vertical microscale patchiness in nano- and microplankton distributions in a stratified estuary. J. Plankton Res. 25, 783-797.

Nagai, S., Lian, C., Yamaguchi, S., Hamaguchi, M., Matsuyama, Y., Itakura, S., Shimada, H., Kaga, S., Yamauchi, H., Sonda, Y., Nishikawa, T., Kim, C.H., Hogetsu, T., 2007. Microsatellite markers reveal population genetic structure of the toxic dinoflagellate Alexandrium tamarense (Dinophyceae) in Japanese coastal waters. J. Phycol. 43, 43-54.

Natsuike, M., Nagai, S., Matsuno, K., Saito, R., Tsukazaki, C., Yamaguchi, A., Imai, I., 2013. Abundance and distribution of toxic Alexandrium tamarense resting cysts in the sediments of the Chukchi Sea and the eastern Bering Sea. Harmful Algae 27, 52-59.

Niemi, A., Michel, C., Hille, K., Poulin, M., 2011. Protist assemblages in winter sea ice: Setting the stage for the spring ice algal bloom. Polar Biol. 34, 1803-1817.

Okolodkov, Y.B., Dodge, J.D., 1996. Biodiversity and biogeography of planktonic dinoflagellates in the Arctic Ocean. J. Exp. Mar. Biol. Ecol. 202, 19-27.

Okolodkov, Y.B., 2005. The global distributional patterns of toxic, bloom dinoflagellates recorded from the Eurasian Arctic. Harmful Algae 4, 351-369.

Orlova, T., Selina, M.S., Lilly, E.L., Kulis, D.M., Anderson, D.M., 2007. Morphogenetic and toxin composition variability of Alexandrium tamarense (Dinophyceae) from the east coast of Russia. Phycologia 46, 534-548.

Paulsen, O., 1904. Plankton-investigations in the waters round Iceland in 1903. Medd. Kommn. Havunders. Kobenh. Ser. Plankt. 1, 1-40.

Posada, D., Crandall, K.A., 1998. Modeltest: Testing the model of DNA substitution. Bioinformatics 14, 817-818.

Ratkova, T.N., Wassmann, P., 2005. Sea ice algae in the White and Barents seas: Composition and origin. Polar Res. 24, 95-110.

Scholin, C.A., Anderson, D.M., 1994. Identification of group- and strain-specific genetic markers for globally distributed Alexandrium (Dinophyceae). I. RFLP analysis of SSU rRNA genes. J. Phycol. 30, 744-754.

Scholin, C.A., Herzog, M., Sogin, M., Anderson, D.M., 1994. Identification of groupand strain-specific genetic markers for globally distributed Alexandrium (Dinophyceae). II. Sequence analysis of a fragment of the LSU rRNA gene. J. Phycol. 30, 999-1011

Selina, M.S., Konovalova, G.V., Morozova, T.V., Orlova, T., 2006. Genus Alexandrium Halim, 1960 (Dinophyta) from the Pacific Coast of Russia: Species composition, distribution, and dynamics. Russ. J. Mar. Biol. 32, 321-332.

Sheng, J., Malkiel, E., Katz, J., Adolf, J., Place, A.R., 2010. A dinoflagellate exploits toxins to immobilize prey prior to ingestion. Proc. Natl. Acad. Sci. U. S. A. 107, 2082-2087. 
Smayda, T.J., 1997. Harmful algal blooms: Their ecophysiology and general relevance to phytoplankton blooms in the sea. Limnol. Oceanogr. 42, 1137-1153.

Stoecker, D.K., Tillmann, U., Granéli, E., 2006. Phagotrophy in harmful algae. In: Granéli, E., Turner, J.T. (Eds.), Ecology of Harmful Algae. Springer, Berlin, pp. 177-187.

Tahvanainen, P., Alpermann, T.J., Figueroa, R.I., John, U., Hakanen, P., Nagai, S., Blomster, J., Kremp, A., 2012. Patterns of post-glacial genetic differentiation in marginal populations of a marine microalga. PLoS ONE 7, e53602.

Tangen, K., Dahl, E., 1993. Harmful phytoplankton in Norwegian waters - an overview. In: Abstracts of the Sixth International Conference on Toxic Marine Phytoplankton, Nantes, France, October 18-22, 1993, p. 195.

Taylor, F.J.R., 1984. Toxic dinoflagellates: Taxonomy and biogeograpic aspects with emphasis on Protogonyaulax. In: Ragelis, E.P. (Ed.), Seafood Toxins. American Chemical Society, Washington, DC, pp. 78-97.

Tillmann, U., 1998. Phagotrophy by a plastidic haptophyte, Prymnesium patelliferum. Aquat. Microb. Ecol. 14, 155-160.

Tillmann, U., John, U., 2002. Toxic effects of Alexandrium spp. on heterotrophic dinoflagellates: An allelochemical defence mechanism independent of PSP toxins. Mar. Ecol. Prog. Ser. 230, 47-58.

Tillmann, U., 2004. Interactions between planktonic microalgae and protozoan grazers. J. Eukaryot. Microbiol. 51, 156-168.

Tillmann, U., John, U., Cembella, A.D., 2007. On the allelochemical potency of the marine dinoflagellate Alexandrium ostenfeldii against heterotrophic and autotrophic protists. J. Plankton Res. 29, 527-543.
Tillmann, U., Alpermann, T., John, U., Cembella, A., 2008. Allelochemical interactions and short-term effects of the dinoflagellate Alexandrium on selected photoautotrophic and heterotrophic protists. Harmful Algae 7, 52-64.

Tillmann, U., Alpermann, T., Purificacao, R., Krock, B., Cembella, A., 2009. Intrapopulation clonal variability in allelochemical potency of the toxigenic dinoflagellate Alexandrium tamarense. Harmful Algae 8, 759-769.

Tillmann, U., Hansen, P.J., 2009. Allelopathic effects of Alexandrium tamarense on other algae: Evidence from mixed growth experiments. Aquat. Microb. Ecol. 57, 101-112.

Tillmann, U., Kremp, A., Tahvanainen, P., Krock, B., 2014. Charaterization of spirolid producing Alexandrium ostenfeldii (Dinophyceae) from the western Arctic. Harmful Algae 39, 259-270.

Toebe, K., Alpermann, T., Tillmann, U., Krock, B., Cembella, A., John, U., 2013. Molecular discrimination of toxigenic and non-toxic Alexandrium species in natural phytoplankton assamblages from the Scottish coast of the North Sea. Eur. J. Phycol. 48, 12-26.

Weissbach, A., Rudström, M., Oloffson, M., Béchemin, C., Icely, J.D., Newton, A., Tillmann, U., Legrand, C., 2011. Phytoplankton allelochemical interactions change microbial food web dynamics. Limnol. Oceanogr. 56, 899-909.

Yoo, Y.D., Jeong, H.J., Kim, M.S., Kang, N.S., Song, J.Y., Shin, W., Kim, K.Y., Lee, K., 2009. Feeding by phototrophic red tide dinoflagellates on the ubiquitous marine diatom Skeletonema costatum. J. Eukaryot. Microbiol. 56, 413-420. 